SB 401

.W3 C66 






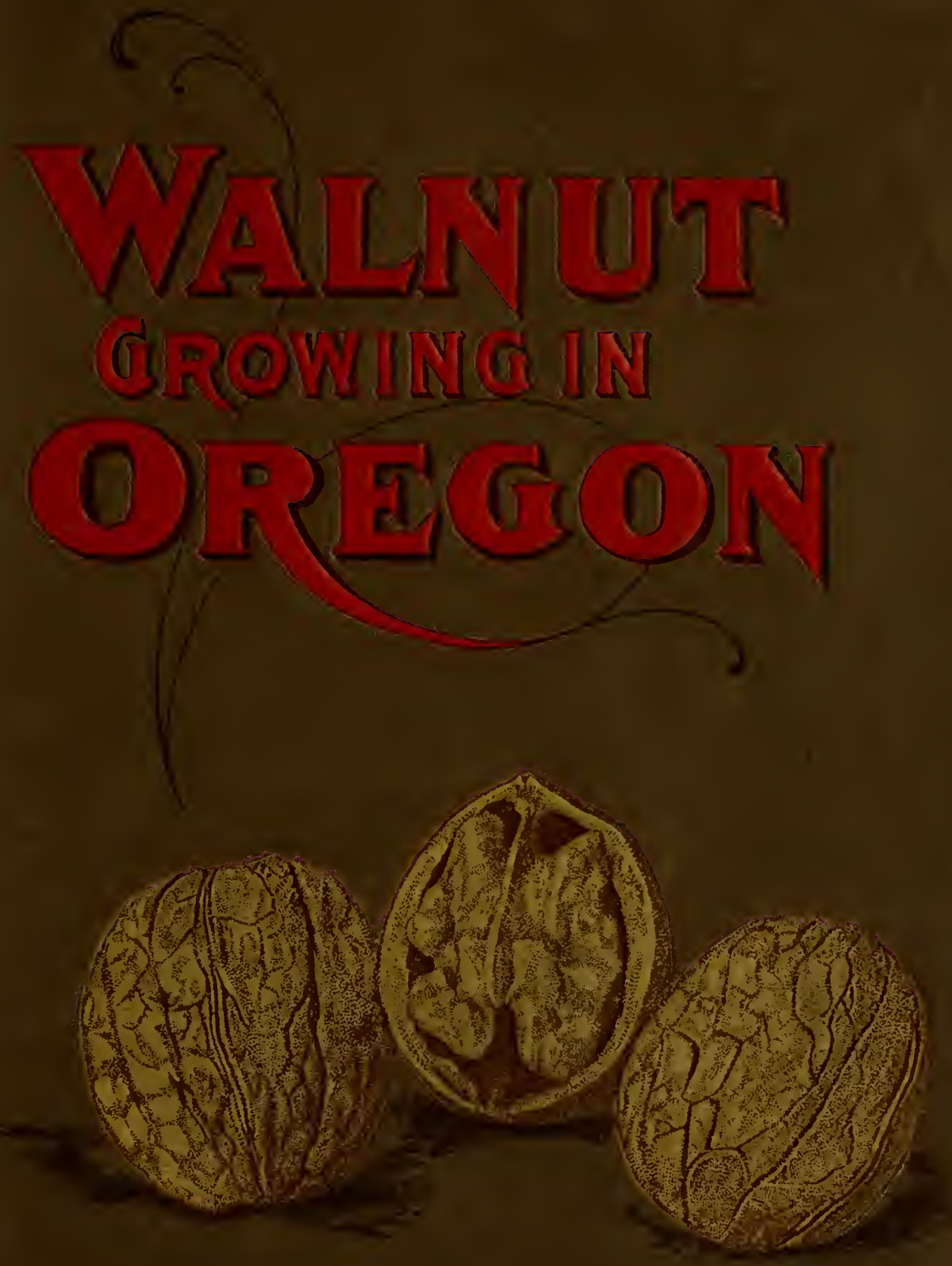



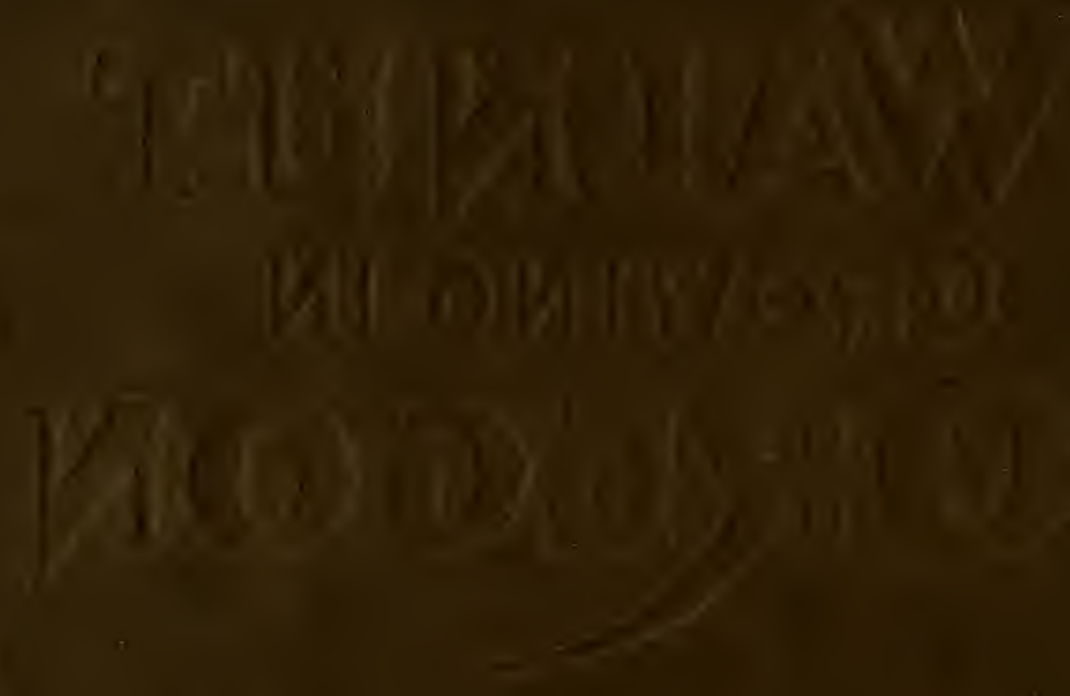

14

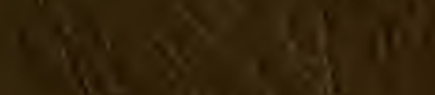

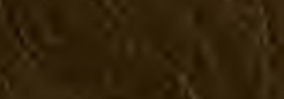

$x-2 k$ 



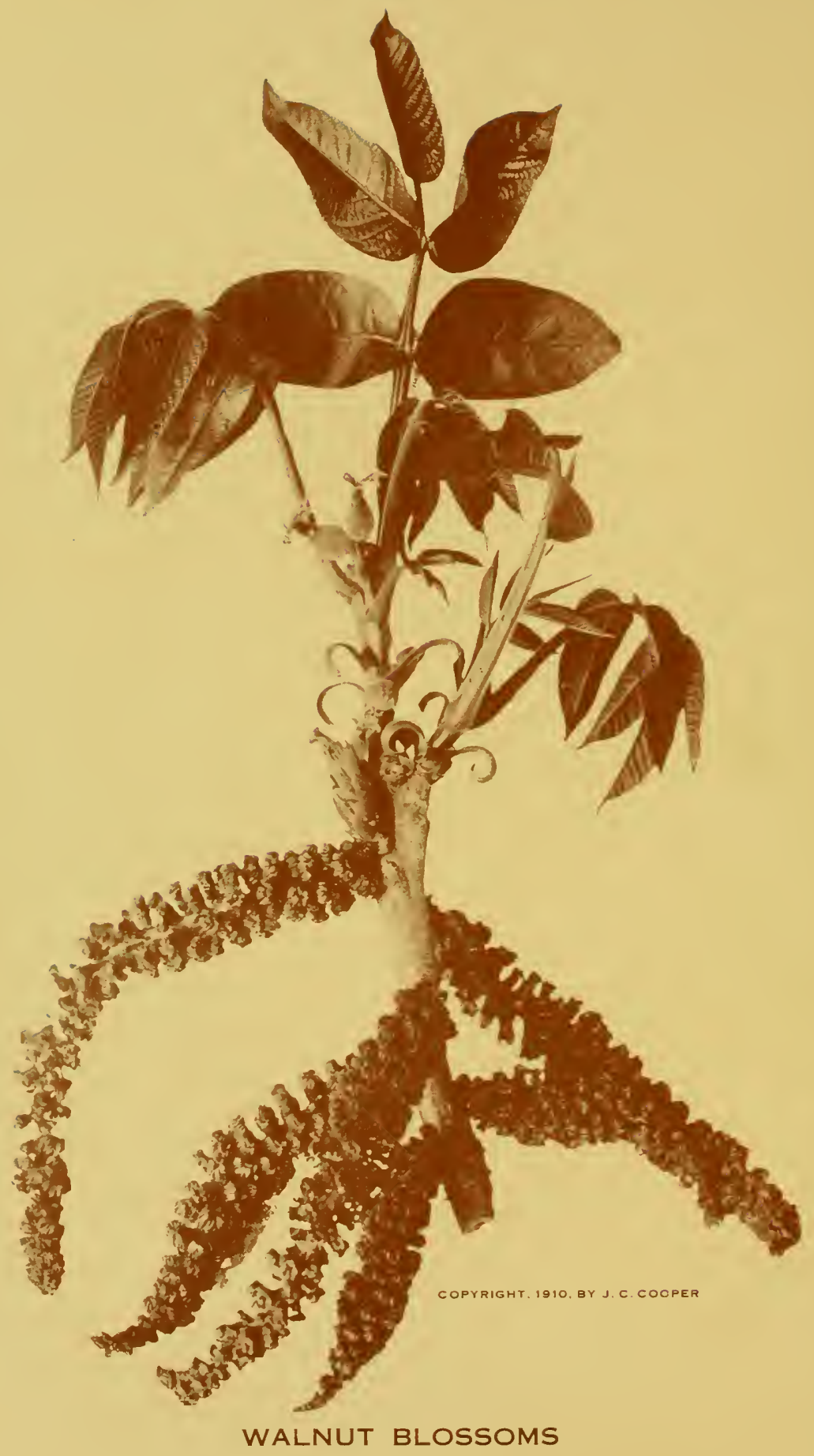




\section{WALNUT GROWING}

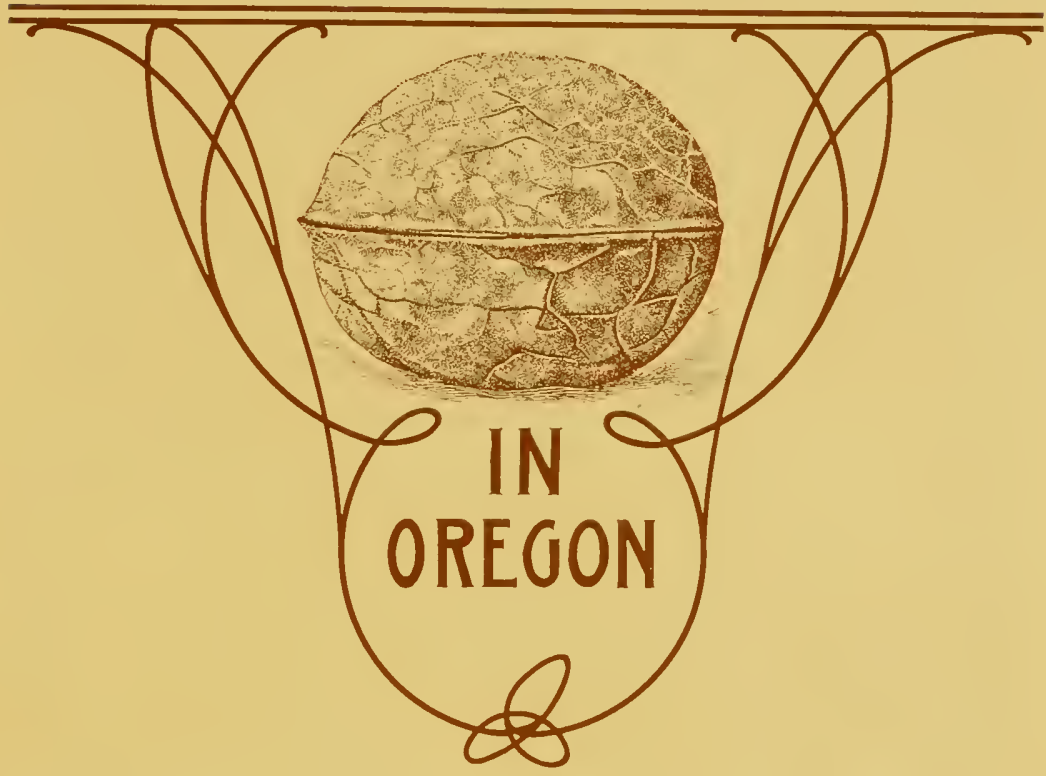

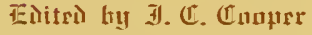
I

(ฺ)

PUBLISHED BY THE

PASSENGER DEPARTMENT OREgON RAILROAD AND NAVIGATION CO. SOUTHERN PACIFIC COMPANY LINES IN OREGON

PORTLAND, OREGON 
${ }^{5}+3 C^{6}$

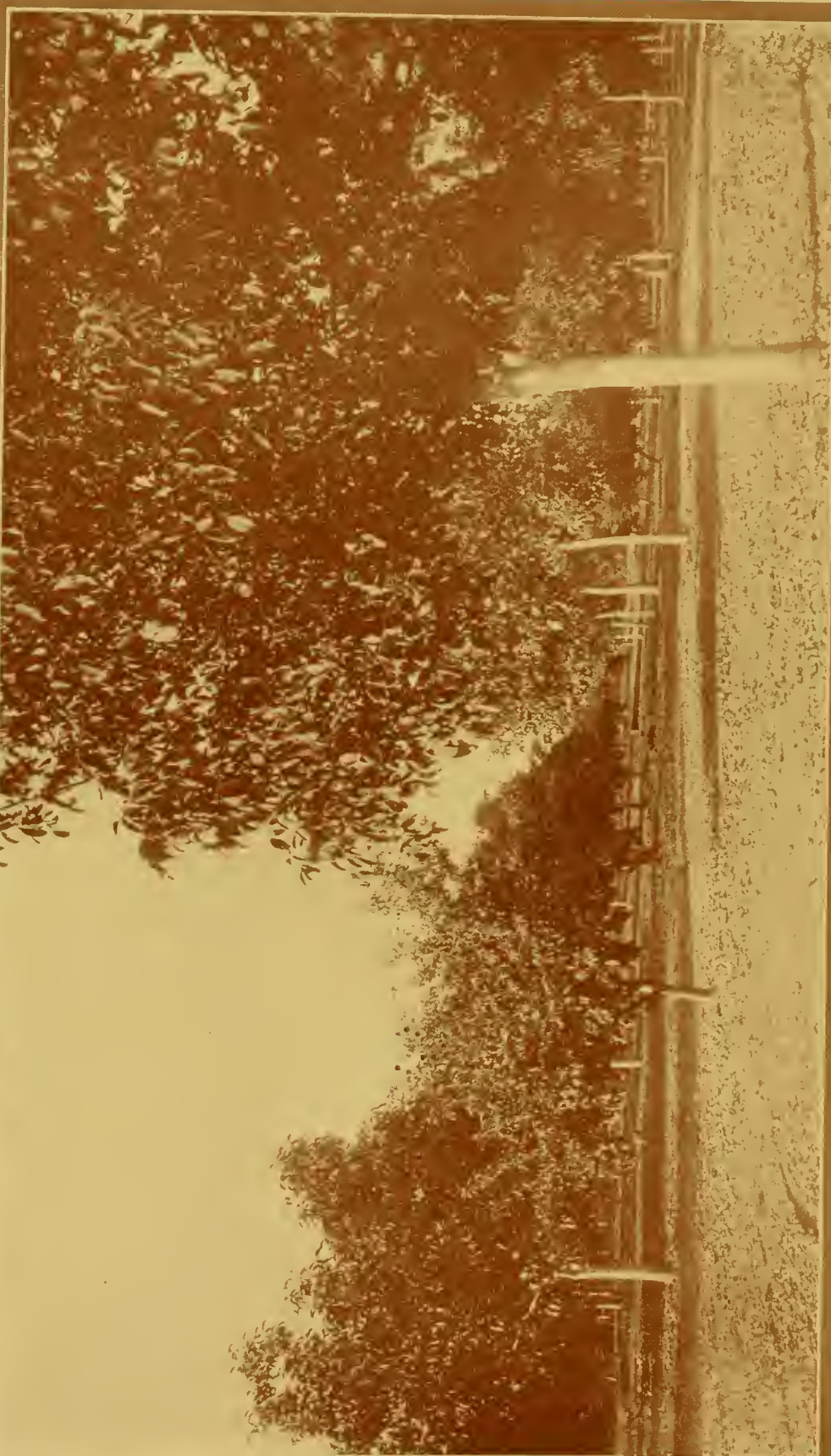




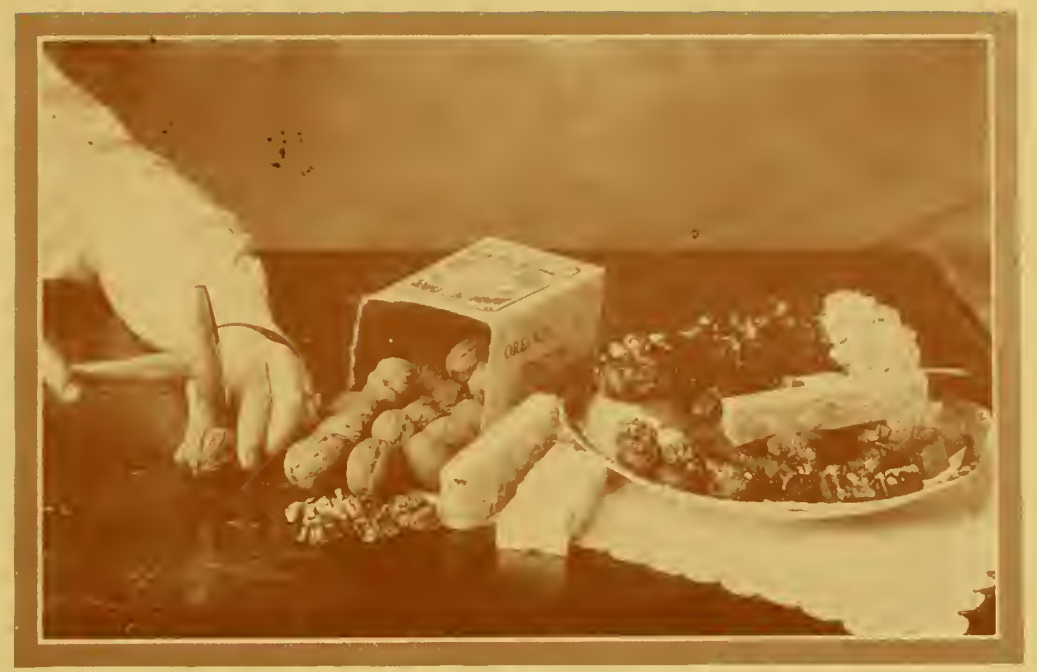

Walnut Confections

\section{WALNUT GROWING IN OREGON A COMING INDUSTRY OF GREAT NATIONAL IMPORTANCE}

English walnuts for dessert, walnut confectionery, walnut cake. walnuts in camly hags at Christmas time-thus far has the average person been introduced to this, one of the greatest foods of the earth. But if the food specialists are heard, if the inereasing consumption of nuts as reeorded hy the Government Burean of lmports is consulted-in short, if one opens his eyes to the tremendous place the walnut is beginning to take among food products the world over, he will realize that the walnut's rank as a table luxury is giving way to that of a necessity; he will acknowledge that the tine is rapiclly approaching when nuts will be regarded as we now regard beefsteak or wheat products. The demand is already so great that purverors are beginning to ask, where are the walnuts of the future to come from?

In 1902, aceording to the Department of Commerce and Labor. we imported from Europe 11.927,432 pounds of English walnuts; each rear since then these figures have increased, until in 1906 they reached $24,917.02: 3$ pounds, valued at $\$ 2,193,653$. In 1907 we imported 32,590,000 pounds of walnuts and $12,000,000$ more were produced in the United States. In Oregon alone there are consumed $\$+00,000$ worth of nuts annually. 
When we consider the limited area suitable to walnut culture in America-California and Oregon practically being the only territory of commercial importance-and the fact that the old World is no longer planting additional groves to any appreciable extent, there heing no nore lands available, we begin to realize the important place Oregon is destined to take in the future of the rahnut inchustry: for in Oregon, throughout a strip of the richest land known to man-the great Willamette basin with its tributary valleys and hills. an area of $60 \mathrm{by} 150$ miles-rralnuts thrive and yield abmulantly, and at a younger age than in any other locality, not excepting their original home, Persia. In addition, Oregon walnuts are larger, finer flavored, and more uniform in size than those grown elsewhere; they are also free from oiliness and have a full meat that fills the shell well. These advantages are recognized in the most indisputable manner, dealers paring from two to three cents a pound more for Oregon walnuts than for those from other groves. Thus the very last and highest test-what will they bring in the market?- has placed the Oregon walnut at the top.

Howerer, in all of Oregon, throughout the vast domain that seems to have heen providentially created to furnish the world with its choicest nut fruit, there are, perhaps, not more than 200 acres in bearing at the present time. The test has been accomplished by individual trees found here and there all the way from Washington and Multnomah eomities on the north, to Josephine and Jackson counties, bordering California. In a mumber of counties but two or three haulsome old monarchs that have rielded heary crops year after yalr, withont a failure for the past twenty to forty years. hear wituess to the soil's suitability ; in other counties, notably Yamhill, sturdy yielding groves attest the soil's fitness. In none of the counties of the walnut belt has hut the smallest fraction of available wahnut lands been appropriaterl for this great industry. People are just beginning to realize ()regrn's ralue as a walnut center and her destiny as the somree of supply for the choicest markets of the future.

Were it practical to plant every unocempied suitable acre in Oregon this rear to walnuts, in eight or ten years the crop would establish Oregon forerer as the sovereign walnut center of the world; and the crop. doubling each rear thereafter for five 


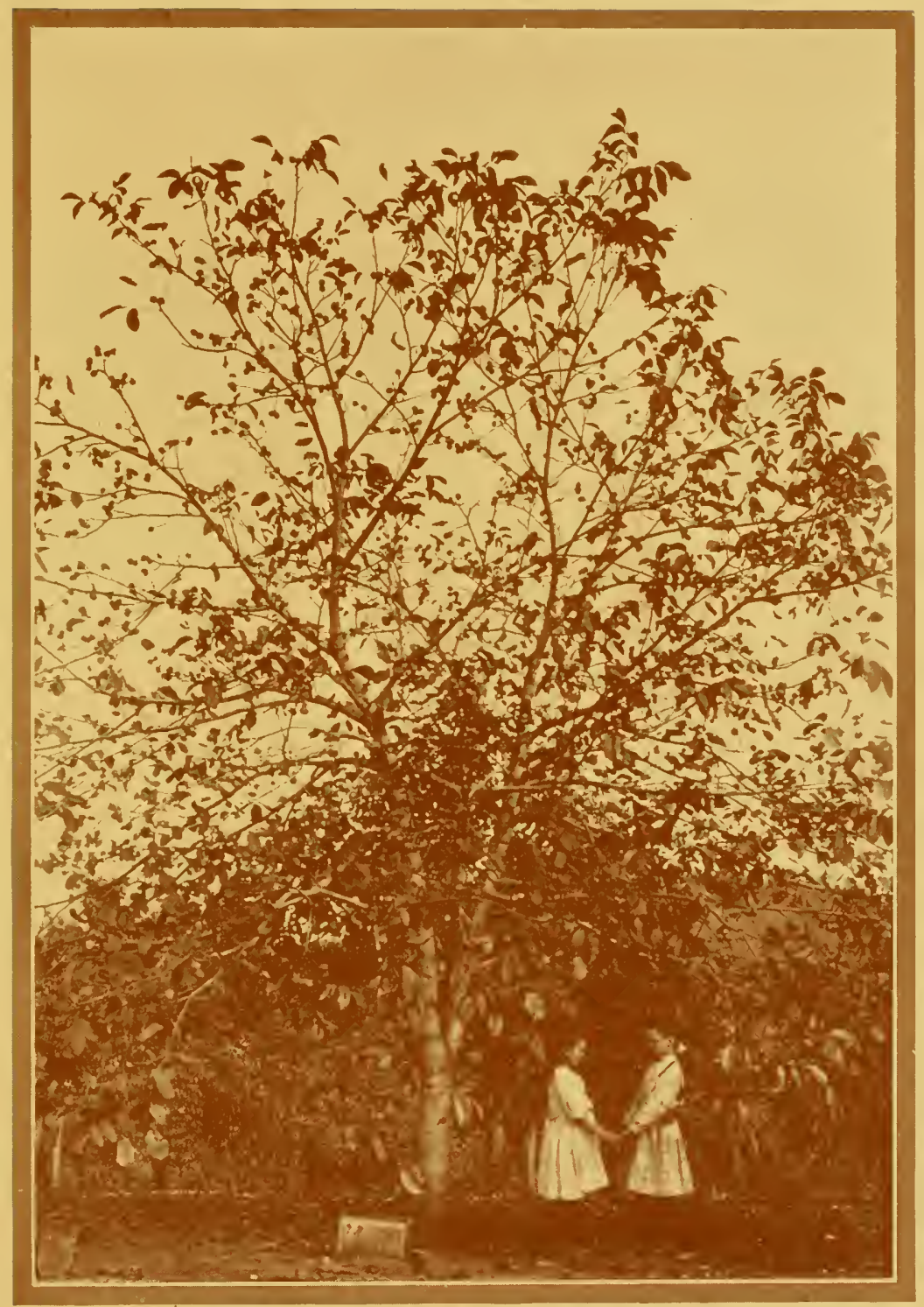

More. Nuts than Leaves. Tree of D. H. Turner.

years, as is its nature, and then maintaining a steady increase up to the twentieth year, would beeome a power in the world's markets, equal, if not superior to that of North American wheat at the present time. 


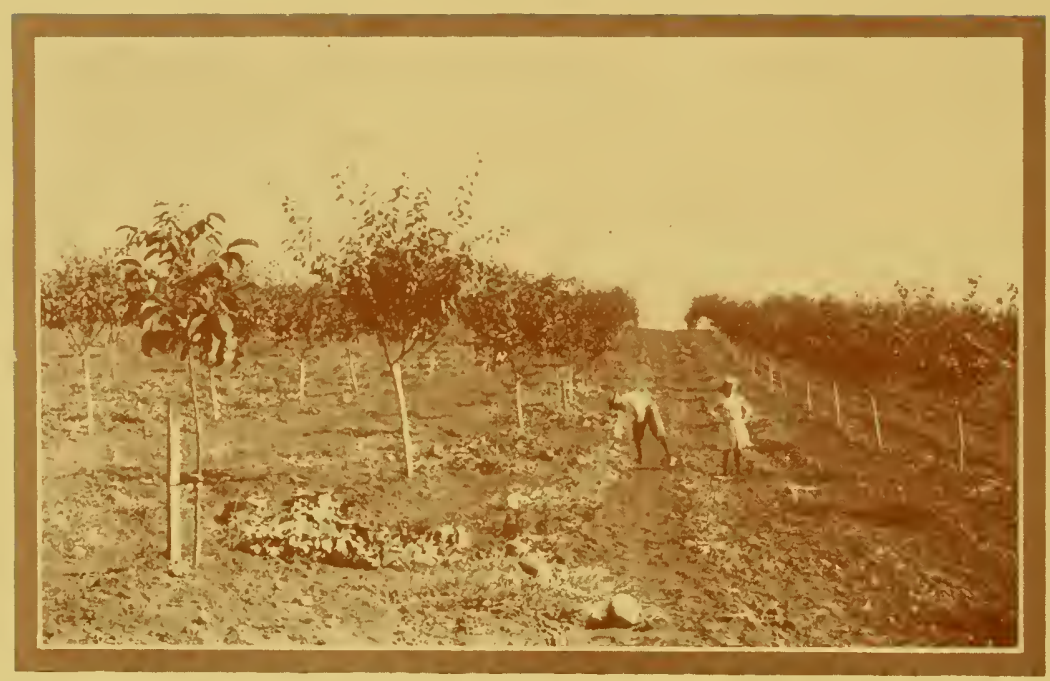

Garden Stuff, Melons, Pumpkins, Prunes and Children growing among the II alnuts. The I'alnuts will in a Few Years put out all but the ('hildren

The United States Year Book for 1908 estimates the food value of the walnut at nearly domble that of wheat, and three times that of beefisteak.

Colonel Henry Dosch, the Oregon pioneer of walnut growing, says: "As a husiness proposition I know of no better in agricultural or horticultural pursuits."

Prof. C. I. Lewis, of the Oregon Experiment Station, writes: "In establishing walnut groves we are laying the foundation for" prosperity for a great many generations.'

Mr. H. M. Williamson, secretary of the Oregon Board of Horticulture, writes: "The man who plants a walnut grove in the right place and gives it proper care is making provision not only for his own future welfare, but for that of his children and his children's children.',

Felix Gillett, the reteran horticulturist of Nevada City, California, wrote shortly before his death: "Oregon is singularly" adapted to raising walnuts."

Thomas Prince, owner of the largest bearing walnut grove in Oregon, expresses the most enthusiastic satisfaction with the income from his investment. and is planting additional groves on his 800-acre farm in Yamhill county, in many cases uprooting fruit trees to do so. 


\section{WALNUT GROWING IN OREGON}

\section{HISTORY IN BRIEF}

The so-called "Euglish" walnut originated in l'ersia, where it throve for many centuries before it was carried to Europe-to England. Germany. France. Spain and Italy-elifferent varieties arlapting themselves to each country. The name "walnut" is of German origin, meaning "foreign nut." The Greeks called it "the Royal nut." and the Romans, "Jupiter's Acorn," and “.Jove's Nut," the gorls having been supposer to subsist on it.

The great age and size to which the walnut tree will attain has been demonstrated in these European comtries; one tree in Norfolk, England, 100 year's old. 90 fest high, and with a spread of 120 feet, rields 54,000 muts a season; another tree, 300 years old, 5i feet high, and having a spread of 125 feet, yields 1,500 pounds earh season. In Crimea there is a notable walnut tree 1.000 rears old that rields in the neighborhood of 100,000 nuts anmually. It is the property of fire Tartal families, who subsist larecly on its fruit.

In European countries walnuts come into bearing from the sixteenth to the twenty-fomth year ; in Oregon, from the eighth to the tenth year; graftert trees, sixth rear.

The first walnut trees were introduced into America a eentury ago by spanish friars, who planted them in Southern California. It was not until comparatively recent vears that the lardier. varieties from France, adapted to commercial use, were planted in California and later in Oregon. They were also tried in other localities, hut without suceess.

Since the prolific productiveness of the English walnut on the Pacific Coast has been assured, many commercial groves have been set unt.

\section{TEST TREES OF OREGON}

The first walnut trees were planted in Oregon in limited number for purely home use, "just to see if they would grow," and they did. Thus the state can boast of single trees close to sixty years of age, each with admirable records of unfailing erops, demonstrating what a fortune would now he in the grasp of their owners had they planted commercially.

In Portand, Oregon, on what is known as the old Dekum place. 13th and Morrison streets, there are two walnut trees, planted in 1869, that have yielded a heary crop every fall sinee their eighth year, not a single failure having heen experieneed. 


\section{WALNUT GROWING IN OREGON}

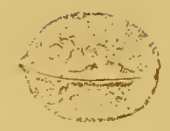

The ground has never been eultivated. The nuts planted were taken at random from a harrel in a grocery store. During the "silver thaw" of 1907, the most severe cold spell in the history of Oregon, one of the trees was wrenched in two, but the dismembered limb. hanging hy a shred, bore a full crop of walnuts the following season.

N. A. King, at 175 Twenty-first street, has some fine. old trees that have not missed bearing a good crop since their eighth year.

Henry Hewitt, living at Mt. Zion. Portland, an eleration of 1,000 feet, has many handsome trees, one, a grafted tree fifteen years old. that has borne since its fifth rear. Another tree of his buds out the fourth of July and vields a full crop as early as any of the other varieties.

In Salem, there is what is known as the famous old Shannon tree, fully thirty years old, with a record of a heary crop every season.

Mayor Britt, of Jacksonville, has a magnificent tree that has not failed in twenty years.

Dr. Finck, of Dallas, has a large tree seventeen rears old that bore 70 pounds of muts in its thirteenth year. and has increased ever since.

C. H. Samson, of Grants Pass, has a grove of 250 trees, now ten years old, that hore at seren years.

Mr. Tiffany, of Salem, has a fifteen-rear-old tree that at thirteen years hore 115 pounds.

Mr. E. Terpening, of Eugene, has four acres of walnuts grafted on the American black, which in 1905 produced 700 pounds, in 1906 produced 1200 pounds, in 1907 produced 2000 pounds, and in 1908 prodnced 3000 pounds. He tried seedlings first, but they were not satisfactory. The Epps and Reece orchard near Engene prodnces abont 100 pounds per tree, at 12 years of age.

Mr. Muecke. of Anrora, planted a dozen walnuts from his father's estate in Germany; they made a splendid growth, and at six years bore from 500 to 800 nuts to a tree.

Mr. Stober, of Carson Heights, planted nuts from Germany with satisfactory results.

Mrs. Herman Ankeny, of New Era, has seven young trees that in 1907 netted her $\$ 15$ a tree. 


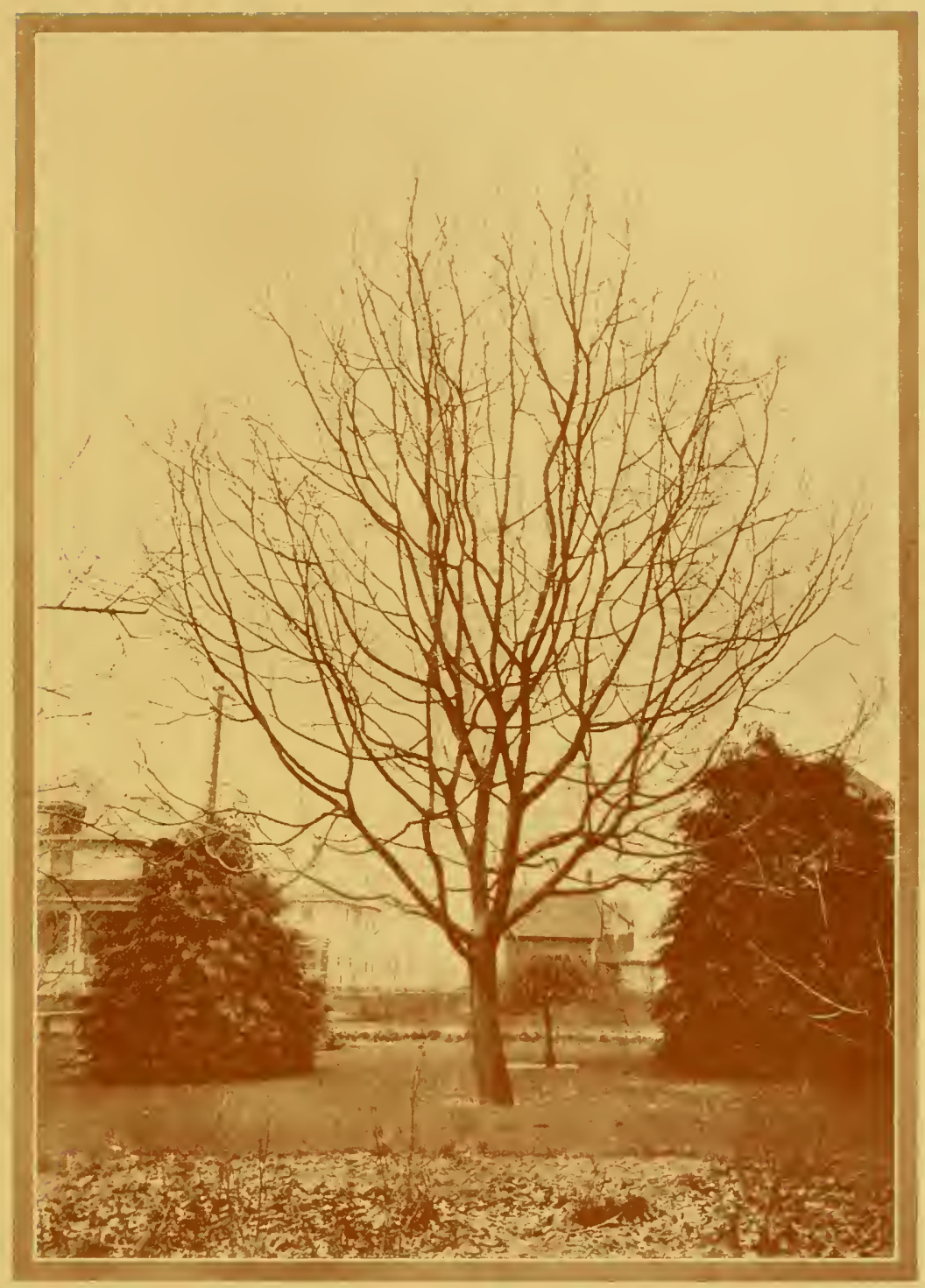

Here is a Santa Barbara soft-shell on the lawn of Mr. E. C. Apperson. in MLMinnville, which at the age of eight years bore 32 pounds of walnuts. It stood the frosts and winter of 1908.'0! and bear's every year; it is now 11 years old, 12 inches in diameter and has a branch spread of 40 feet. 


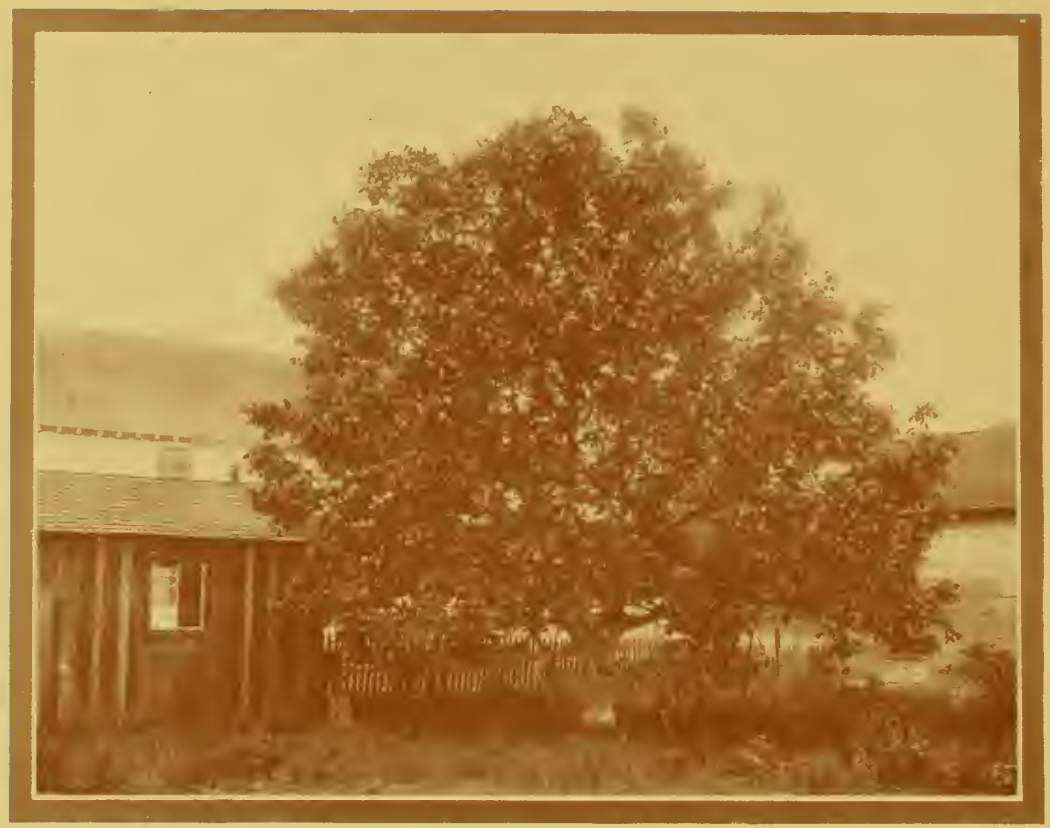

The "Cozine" II alnut Tree

Cozine tree on A street. Mc.Minnville. Seedling. 15 years old; bears good crop of nuts every year. At 14 years old the (rop was 125 pounds. Is 16 inches in diameter and has a spread of t2 feet.

One sixteen-year-oll tree near Albany netted its ownor $\$ 30$.

A Franquette walnut near Brownsville yielded eight bushels at ten years.

The French varieties planted in and around Vancourer commenced hearing at seven years, and have never failed. Prominent growers are A. A. Quaruberg, A. High, Mr. H. J. Biddle, C. G. Shaw.

In Yamhill county, Ed. Greer, James Morison, F. Wr. Myers, D. H. Turner and Bland Herring all won prizes at the first walnut fair held in the state, on nuts from their groves.

\section{WOOD OF THE ENGLISH WALNUT}

The wood of the English walnut is very hard and close grained, and nearly as hard and tough as hickory. It will no doubt be valuable for furniture, finishing lumber and any other use that may require a first-class hard wood. 


\section{WALNUT GROWING IN OREGON}

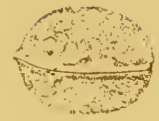

\section{YOUNG GROVES OF OREGON}

The Prince walnut grove of Dundee, Yamhill comnty, thiths the soul of the onlonker with its beanty, present fruitfulness, and great promise. Lying on a magnifieent hillsicle, the long rows of evenly set treses-healthy, luxurions in foliage, and filled with nuts -present a picture of icleal horticulture worth going many miles to see. There is not a reed to mar the perfect appearance of the well-tilled soil; not a drael limb, a broken hranch, a sign of

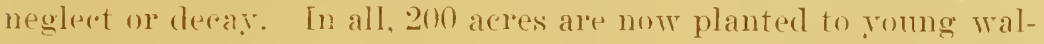
nuts, new areas being added each season. From the oldest grove, about forty-fire acress. the troes from twelve to fompteon rears oll, there was marketer in 1905 betweon two and three tons of walmuts; in 1906 between four and five tors; in 1907 tom tons were harvested, hringing the highest market price. 18 and 20 eents al pomnd wholesale, two cents nore than California muts. The (rop for 1908 was at least one-third heavier than for 1907 . One tree on the l'rince place, a Mayette, that has received extra cultivation, by way of experiment, now twelve years old, has a spreaci of thirty-eight fort, and yidded in its eleventh year 125 pounds of exeellent unts. Mr. Woods, the superintendent of the Prince place, consilers walnut growing a comparatively simple matter; he advorates planting the mut where the tree is to grow, choosing nuts with eare; and then thomgh cultivation. The soil is semi(-layey, red, hill land.

Near Albany, Linn comnty, 700 acres are planted; the soil is a rich loam, and seems admirably adapted to walnuts.

Near Junction (ity, in Lane county, there are 200 aeres of young trees. Every condition seems present for the best results.

Eugene has two small groves.

Yamhill county, where the greatest demonstration thus far has been made. has close to 3,000 acres in yonng trees, the planting having been both on hill and valley lands.

At Grants Pass. Josephine county, there is a promising grove of 600 young trees.

Near Aurora and Hubbard, Marion county, where the soil is a rich, black loan, rather low, a number of young groves are making a growth of four and five feet a season.

J. B. Stump, of Monmouth, Polk county, has a vely thrifty young grove. 


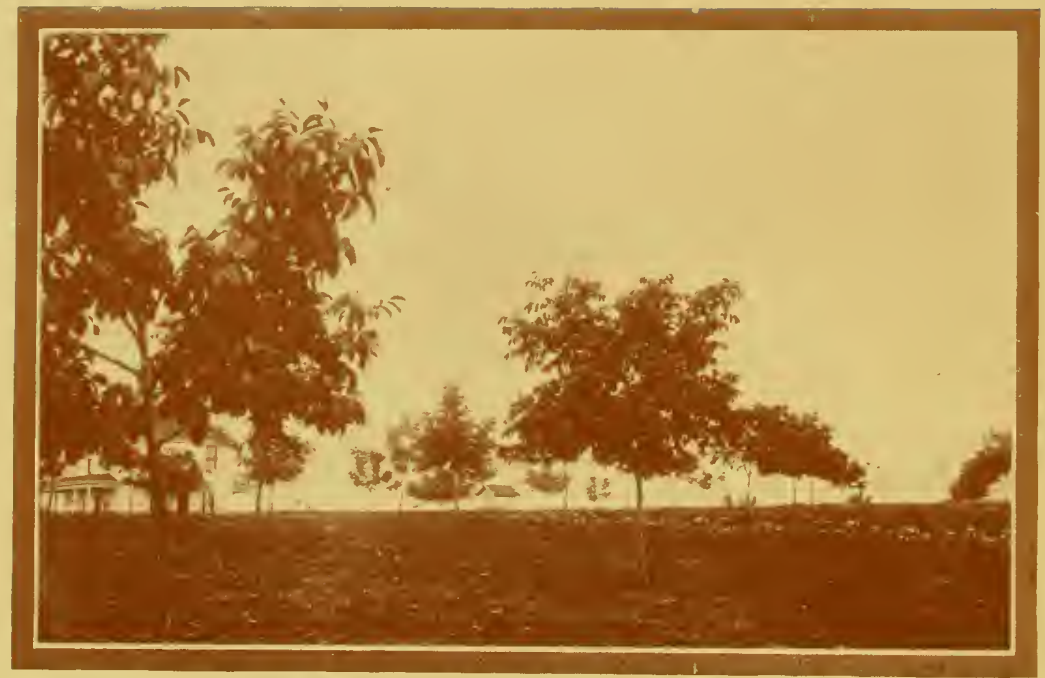

A Young IT illamette lalley Grove

This is a view of a part of the R. Jaeobson orchard one and one-half miles west of Mc.Minnville. The land was bought for $\$ 60$ per acre and when planted to walnuts sold for $\$ 200$. The orchard is now five rears old and could not be bought for $\$ 600$ per aere. It is located on a hill 150 feet above the level of the valley.

The largest single grafted grove in Oregon is situated one mile from Junction City, the property of A. R. Martin. He has sixtyfive acress.

Washington comnty is rapidly aequiring popularity as a walnut center. many fine orchards being now planted. Mr. Fred Groner. near IIillsboro, is now planting 100 acres to grafted trees. The Oregon Nursery Company is establishing large walnut nurseries in Washington county.

In Douglas county, vicinity of Drain, little attention has heen paid to walnut enlture, but a sufficient number of trees are doing well to insure good results from large plantings.

In Jackson county, near Medford, a mumber of roung groves have been planted, and individual trees throughout the Rogue River Valley furnish ample evidence of correct soil and climatie conditions in that section. Even when apple trees have been canght by frost the walnuts have eseaped uninjured, bearing later a full erop.

In Tillamook county only sufficient trees have been planted to demonstrate farorable soil eonditions. 


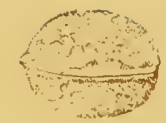

While western Oregon is miversally ronceded to be the natural waluut center, eastern Oregon also has its localities where walnuts bear heavily, and will prove a good commercial crop. In Baker county there are thousands of acres of land adapted to walnuts; young groves are being planted, and a number of trees have produced fine crops.

When one considers the rears of the future when the trees of each of these young groves will lift their symmetrical heads fifty, sixty, ninety feet into the air, laden to full capacity with a plenteous crop, each October dropping their golden-brown nut harvest that falls with the clink of dollars to the commercialminded, but with an arcompaniment of finest sentiment in the hearts of those otberwise inclined, one turns away with a desire to repeat the wistom of these pioneer planters and start a grove of his own. With what grander momument could one commemorate his little span on earth?

\section{LOCATIONS FOR ADDITIONAL GROVES}

Mnch is heard, in a general way, of necessary climate and soil conditions for walnut culture, some giving preference to the hillsides, others to valley lands: some contending for a deep, rich loam, other's for sandy soil. l3ut a careful examination of the soils of Oregon and the trees now bearing thereon produces convincing evidence that almost any deep. rich, well-drained, western Oregon soil-and some in eastern Oregon-not underlaid by hardpan. will insure a good havest, providing the right varieties are planted. The whole question resolves itself into a matter of intelligent choice of trees to suit varying conditions.

For example, the famous Prince grove is producing magnifirent crops on soil decidedly clayey; but the place is thoroughly cultivated and careful selection has been made of hardy trees, the Mayette being preferred.

Another young grove is proving that walnuts do well on clayey hill land of buckshot nature, where the drainage is good and there is no rock or hardpan.

In contrast with the hill land, young groves are making admirable growth on the rich loam about Aurora and Me Minnville.

Mr. Henry Hewitt, of Portland, has fine, young seedlings on a hillside, elevation 1,000 feet, that made four feet of growth in one season. 


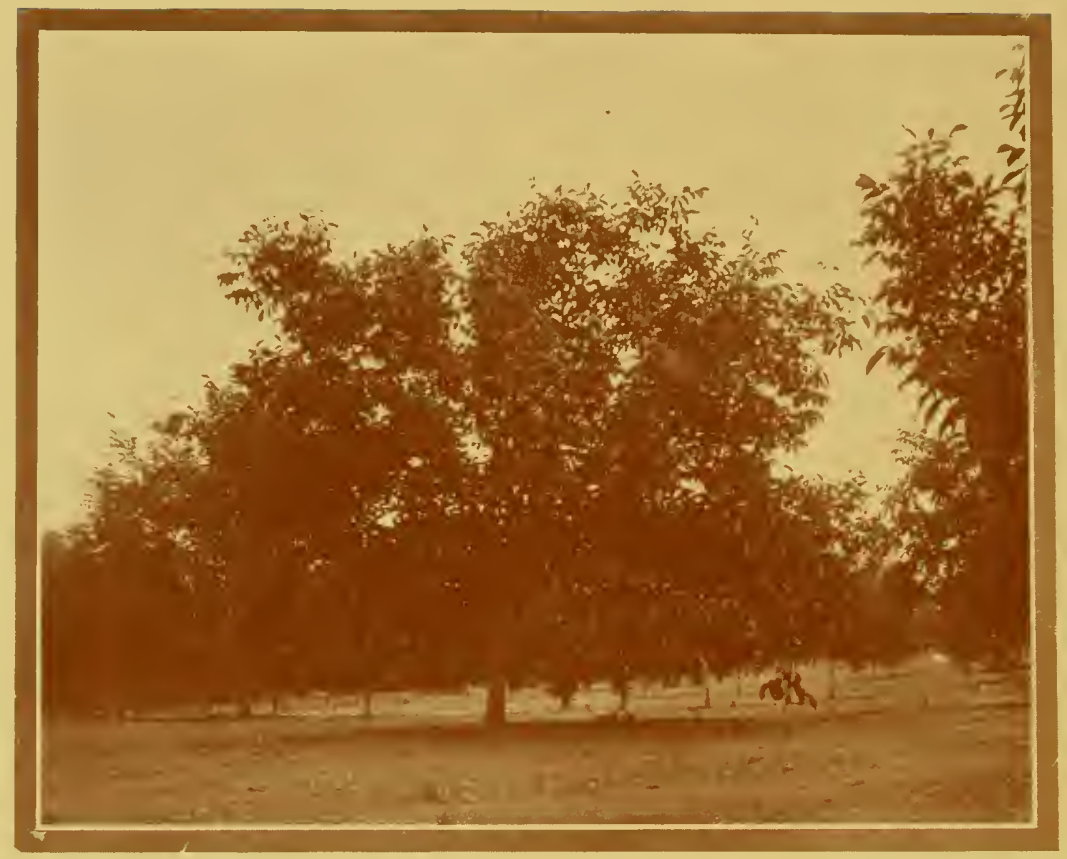

Tieu of a Tamkill Orchard

In the neighborhood of all these groves, there are hardy, bearing trees that amply foreshadow the future of the larger plantings. Colonel Henry Dosch, the pioneer walnut grower of Oregon, who has experimented rather thoroughly. even goes so far as to claim that rocky soil is not oljectionable. providing there is no liarlpan.

In this, as in all other horticultural pursuits, naturally the richer soils are best : lut the industrious horticulturist, by cultivation. fertilization, and proper care. can produce a fairly good grove un unfarorable lands. Howerer, so much of Oregon is farorable by natme that growers will hardly unclestake to emrich the few less desirable areas for a good many years to come. Land that on the Atlantic slope would be seized readily enough. in Oregon is passed hy, as there is still so much mutouched that nature has made ideal. Yaars hence growers aceustomed to the less fertile conditions of the far ast will undoubtedly turn their attention to even the few poorer areas in Oregon, and make of them glowing garden spots. 


\section{WALNUT GROWING IN OREGON}

It is a simple matter to determine the presence of hardpan; you have but to make a series of tests-four or five to the acrewith a plumber's auger; and this care should be taken in every area where soil conditions have not been fully determined.

\section{PLANTING}

Gather the walnuts during the fall or winter, fall is better, and put them in boxes about the size of ordinary apple boxes, putting in first a layer of sand (the sandy loam along the valley streams is excellent) about four inches deep, then a layer of walnuts about the same depth, then cover these over with three or four inches more of sand. Place these boxes out in the weather on the ground where the water will not rise in them. The reason for putting the walnuts in boxes instead of beds, as advised by some planters, is that the boxes may be taken to the field or nursely and the nuts lifted carefully from the sand and placed where they are to grow. It sometimes happens in a wet and backward spring that the walnuts will sprout before the ground is ready for planting, in which case they must be handled with the tenderest care and not exposed to the atmosphere any longer than can be helped.

One grower had a bed of hybrid black walnuts. The season was late and when the ground was ready for planting many bad started to grow. He engaged some boys to grabble out the nuts from the sand beds, urging care, but many of the best were broken and injured. Some of them had sent down a taproot nearly or quite three inches in length. 'These early ones, under' proper conditions, are the most vigorous and surest growers, but in the treatment they received many were injured and killed.

Black walnuts are slow to germinate, sometimes laying in the ground two years before sprouting. But if kept properly they will start by June or July.

For the nursery the ground should be plowed deep and thoroughly pulverized. Plant the nuts 6 to 12 inches apart in rows about 3 feet apart. Put a handful of the sand from the boxes around each walnut. Our soil will appreciate the sand or silt from the drifts along the valley streams, as it has proven to be one of the best fertilizers known. If anyone doubts this let him try a quantity of it on his kitchen garden. 


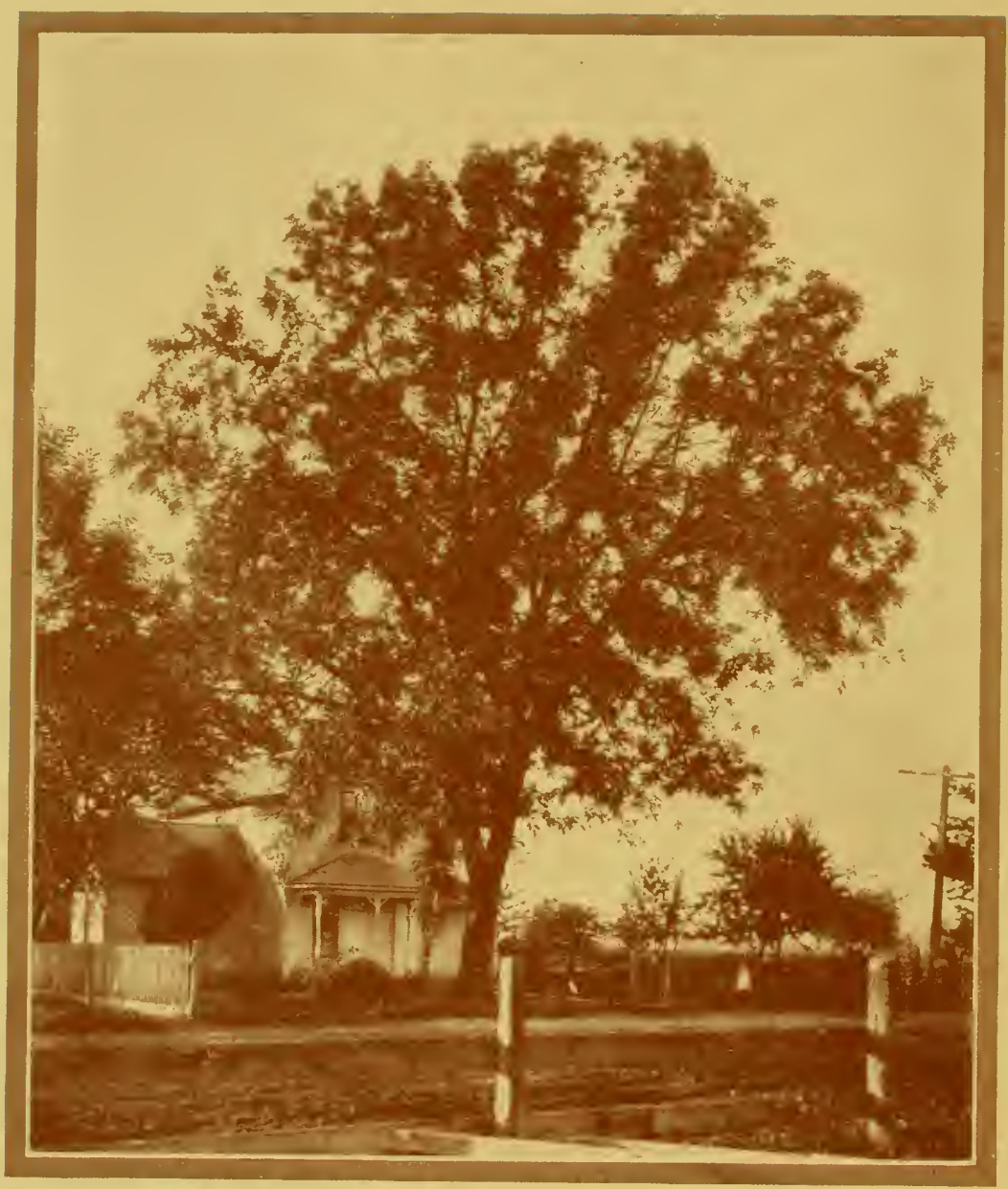

A California Black W'alnut near. Mc.Minnville

On the Ford place, near the North Yamhill bridge, is one of the finest trees in the county, 33 inches diameter, height 75 feet, spread of hranches 60 feet. Bears an abundance of nuts every year. It is $3 \pm$ rears old. The seeds are much used to raise grafting stock.

Nearly all of the black walnut seed produced in the Willamette valley will partake more or less of a mixed or hybrid nature, whether from a California black. Japanese black, or American black. The black walnuts are very susceptible to cross pollinization and the English walnut also, for be it known that

With wandering bees and the sweet May breeze, That virile tide goes far and wide. 


\section{WALNUT GROWING IN OREGON}

The nut should be planted two or three inches deep. A good authority says to place the nut on its side as it would lay after falling from the tree. If the nut is sprouted make a hole in the well pulverized soil and put the root carefully down into it.

The best way for planting in the orchard is to bore a hole with a post or well anger 4 or 5 feet deep where the tree is to grow, put in a stick of dynamite and break up the ground thoroughly.

Or, better still, bore down to permanent moisture and fill the lower hole with good soil or other root food, then dynamite 4 or 5 feet of the upper section of the hole. Nothing will produce a vigorous and thrifty tree like a deep and vigorous root sytem, and no tree responds to cultivation and care as does the walnut. white or black. After bursting up the soil, excavate and put in a half bushel of barn or other mould, well rotted. This will force the tree in the earlier years of its life and can be no hindrance to it later. Cover the manure with a foot or two of soil and plant. Both before and after planting the ground should be ploughed and harrowed until it is as mellow as an ash heap. Plant threc or four muts in a hill 6 to 8 inches apart and at the end of the first season's growth pull out all but the most vigorous one. For transplanting from the nursery the same methods should be followed in the preparation of the hole and the soil as in planting the seed muts. If one wants to lay the foundation for a fine orchard and a fine fortune as a consequence, these preliminary steps must not be neglected. Because in time you expect this tree to pay you a rental of $\$ 8$ to $\$ 12$ a month. If you are building a cottage that would bring in that sum, you would put in much more work and money besides. The wise grower would rather have a man plant six trees for him in one day than sixty. The walnut is usually a very vigorous tree and will fight its way among adverse conditions and surroundings, but its golden showers are much more abundant if it is protected from the scars of battle, especially in its youth. It almost seems to respond to the love and affection given to it by a kind master. Animals respond to kindness, and why not the domestic trees? It will pay you a big salary after a while when your other bank accounts and your health and strength fail. 


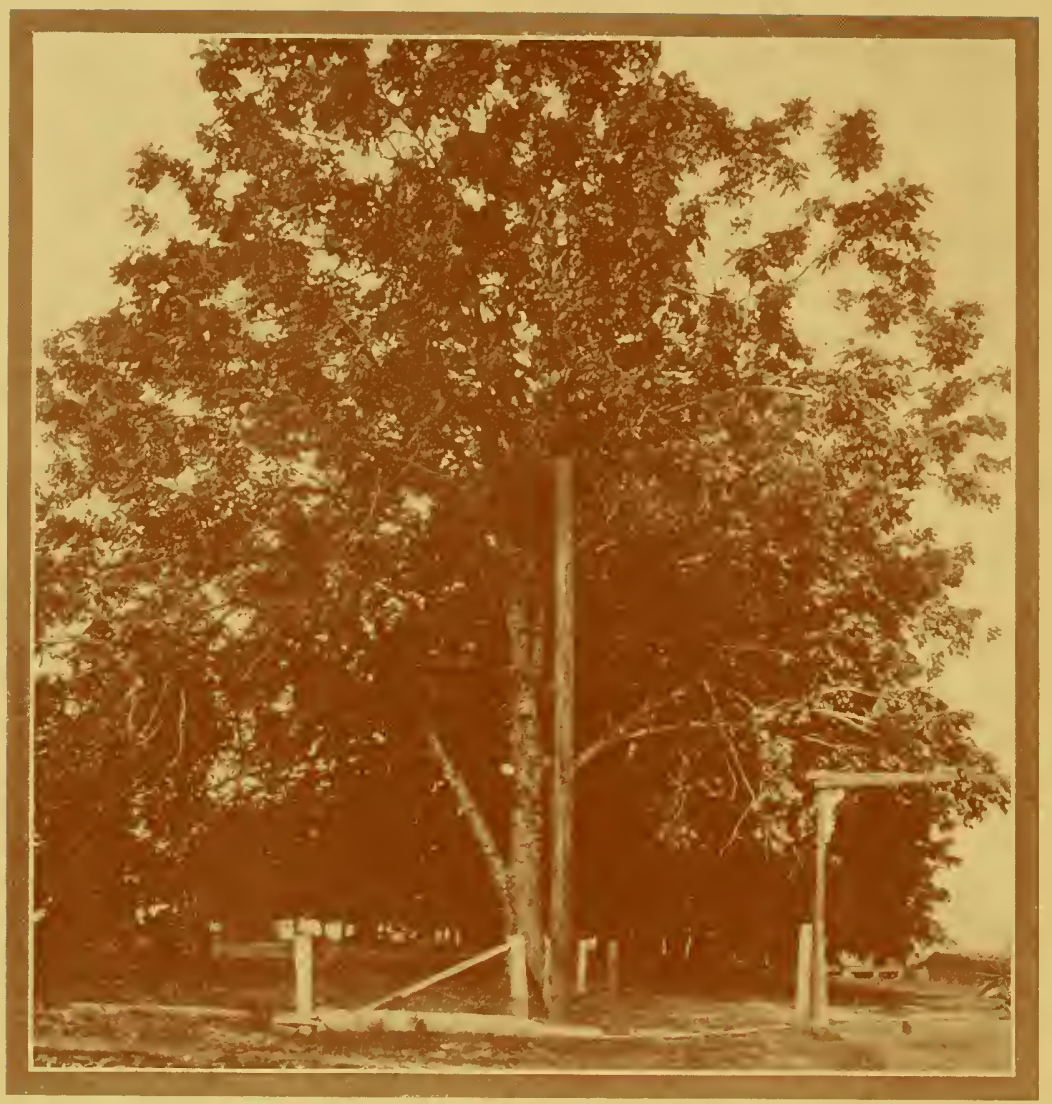

A merican Black Walnuts

A magnificent row of nine American black walnuts, 35 or 40 years old. The tree in the foreground is 29 inches in diameter of trunk. The tallest of the trees is nearly 60 feet and they have a spread of more than 70 feet. They are at the residence of Dave Johnson on the Portland road about 8 miles from MeMinnville. Seed from such trees as these would produce the very best trees for grafting upon.

There are very few California blacks of pure strain in the country. The hybrids or crosses with the Ameriean or eastern black walnut are better trees for grafting stock than the pure Californias. They are more hardy and better adapted to our climate. 


\section{WALNUT GROWING IN OREGON}

\section{WHAT TO PLANT}

Horticulturists of equal fame and experience take different views on the subject of planting, some contending that the nut should be planted where the tree is to grow ; others that seedlings are the thing, and still others that trees should be grafted. And as all three plans have produced good results in Oregon, the individual planter may take his choice, aecording to the circumstanees in which he is situated. The truth is that the walnut is one of the hardiest of trees, and with good attention will not disappoint if the right kinds are properly started.

In planting walnuts to raise seedling trees the best available seed muts shomld be used. Select the hest and most prolific variety and the one most suited to the elimate.

It is claimed that the nuts from a grafted tree will produce the best seedling trees. This may be true as a rule, as the mut from such a tree will have some of the characteristics of the stock upon which the parent tree was grafted. It may inherit some of the resistant qualities of the black walnut or the rapid growth of the California hybrids. It may have early ripening qualities. It is well to consider all these points as well as the quality of the nut when selecting seed.

By careful selection and cross pollination many and better variefies will be produced. No doubt a nut superior to auy that has yet appeared in any country will yet be originated in the Willamette Valley, as in the case of the Bing and Lambert eherry and some other fruits.

The improvement of the walmut in this seetion is one of the most fertile fields of investigation to be found anywhere and one that promises big reward to the suceessful eulturist. And the walnut grower need not wait long to find whether he has a prize or not, for just as soon as the little sprout comes from the ground and has hardened sufficient to handle, a skillful grafter can place it in a hearing tree and the second or third year know the result of his experiment by the production of fruit, and this not more than three or four years from the planting of the seed.

The advantage of planting walnuts, providing you seeure first generation nuts of the right variety for your soil and atmospherie eonditions, is in simplicity and inexpensiveness. You merely pureliase your muts of a reliable confren, or from an isolated grove 


\section{WALNUT GROWING IN OREGON}

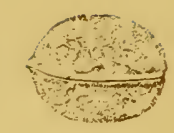

of one variety (many send direct to France, where pure strains can be more readily gotten), and in February plant them on their sides in a shallow box of moist sand; keep in a cool place. In April, or as soon as they sprout, dig a hole $2 \frac{1}{2}$ or 3 feet deep, put in surface loam, and plant three or four nuts to a hole about 2 or 3 inches deep. They will come up by June and make a growth of a foot or so the first season.

It is contended by many that nothing is gained by planting seedlings in the nursery, as the set-back from transplanting prevents their bearing any earlier than trees of the same age grown from nuts.

Grafted trees, on the other hand, are difficult to obtain in large numbers, are expensive, but produce nuts of uniform size and beauty, and the pollination is said to be more sure.

The industry is still too young in Oregon for the final word to have been spoken on this point. The future will undoubtedly add much valuable information as larger experience supplants theory with facts.

The vital point is to plant good nuts or reliable seedlings from a pure strain.

In choosing varieties be governed by your location. If frosts are to be feared get late-blooming varieties, the leading ones established in Oregon being the Mayette and the Franquette. Other varieties will undoubtedly be introduced in the next few years that will withstand frost in regioms where walnut planting now seems impractical. Mr. Henry Hewitt's one tree that blooms the fourth of July, at an elevation of 1,000 feet, is evidence of the possibilities in this direction. Air drainage is necessary.

The tested varieties in Oregon to date, and the results, are as follows :

Mayettes (the famous "Grenoble" of commerce) and Franquettes are first choice for hardiness and for reliable commercial crops, the nuts being of good size, fine flavor and in every way meeting the highest market demands.

Proeparturiens bear earlier than other varieties, are very productive and as fine flavored as a hickory nut. but the nuts are small for best commercial prices.

The Chaberte is a hardy tree, good for the uplands. and prolific; a delicious nut, small but excellent for confectioner's use.

The Ford Mammoth, Glady and Bijon are too large to find favor for commercial purposes. 


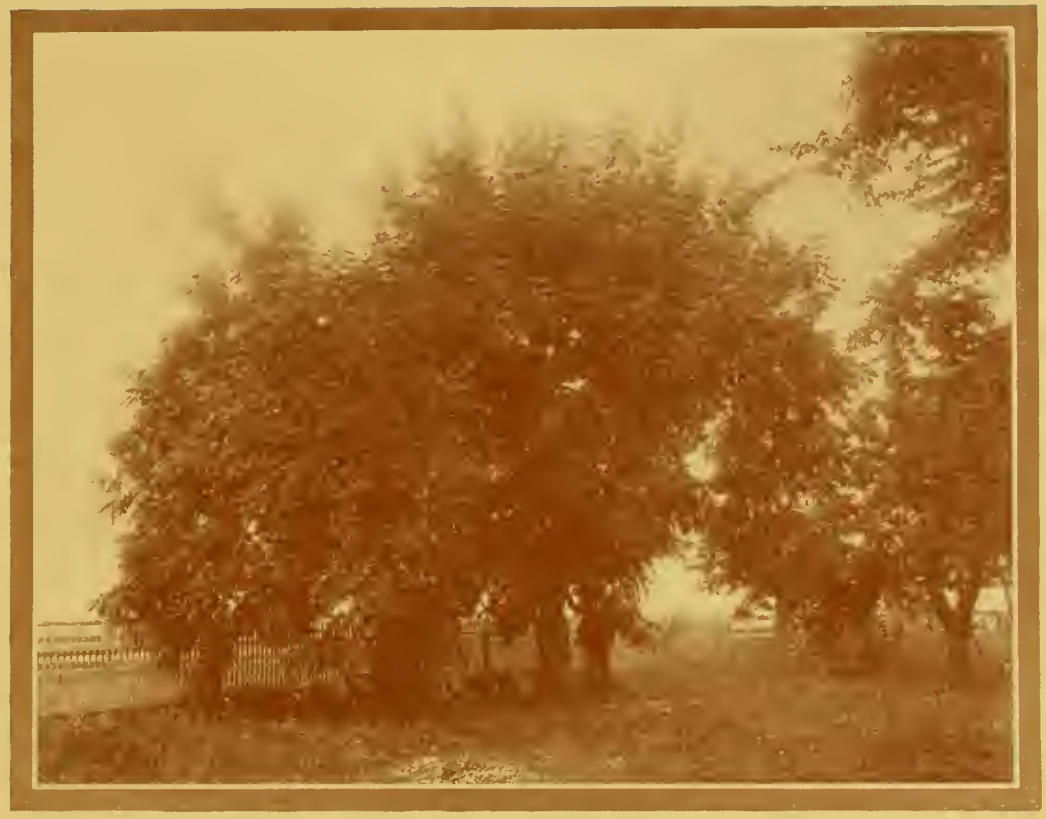

A Fine Japanese Hybrid in Lafayette

The Parisienne, Meylan and Lanfray are newer varieties that give much promise, but have not been thoroughly tested.

II. M. Williamson, Secretary Oregon State Board of Horticulture. in an article says:

"The extremely unfavorable weather of the past winter (19015-9) has been one of the best things which could have happened to many heedless persons who planted walnut trees without first taking pains to learn anything about the business. The destruction of many young trees of the Santa Barbara trpe was a blessing to those who planted them, and the planters deserve no sympathy, for the warnings not to plant trees of that type have been ample for many year's past.

"The fine condition of suitably located groves of walnut trees of Franquette, Mayette and other French varieties, after a winter which proved the most trying to fruit trees of all kinds which we have known during a long period of years, has given firm confidence to those who are leading in the development of the walnut industry in Oregon.

"The varieties which are best adapted to culture in this state are those which produce the finest nuts known to the world." 


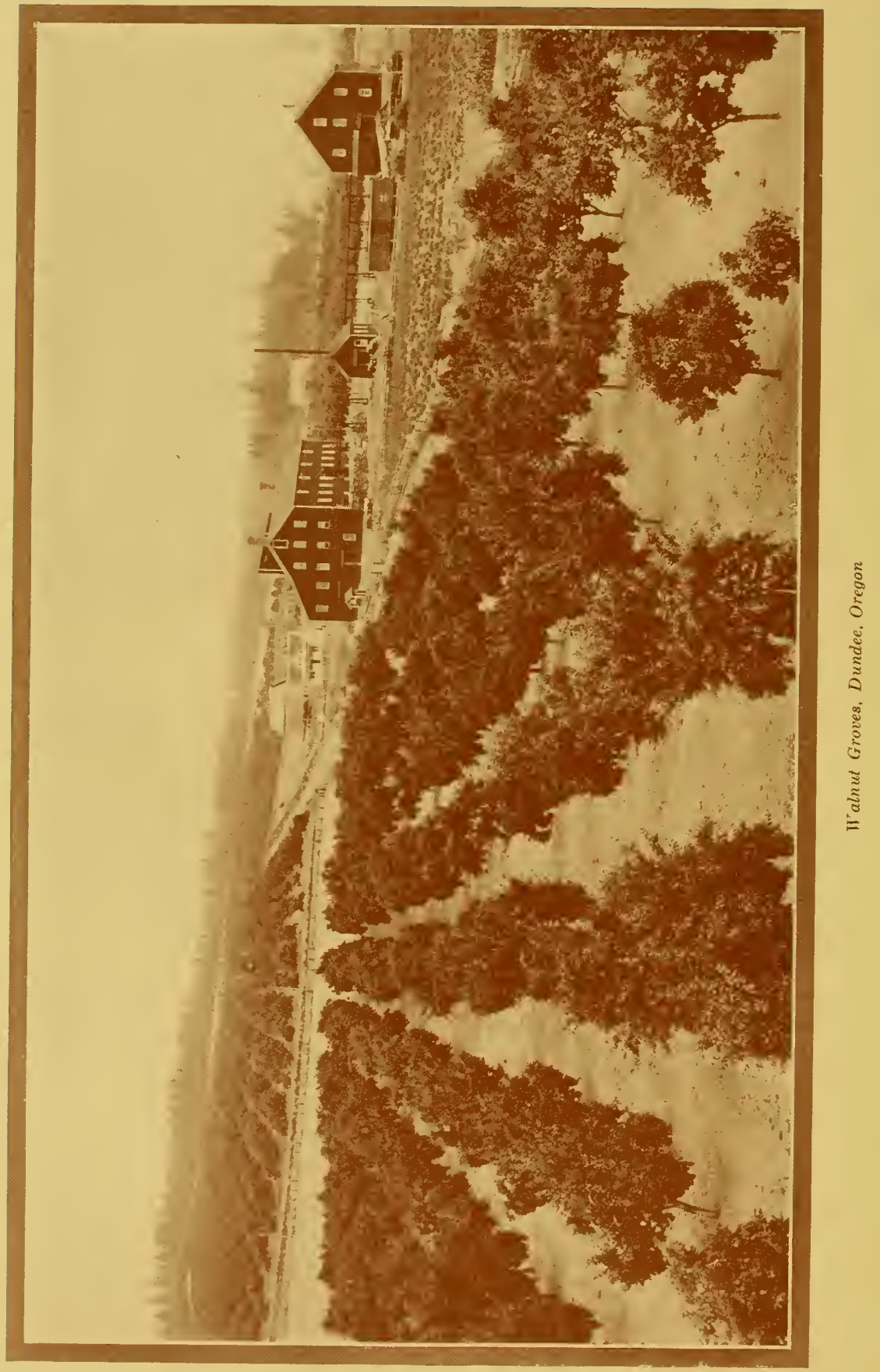




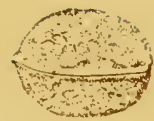

\section{SEEDLING WALNUTS}

The leading commercial orchard in the state is that of Mr. Thomas Prince, of Yamhill county, and is composed almost entirely of seedling trees. The history of this orehard is best told by Mr. Prince in the following very conservative letter:

"About 17 years ago the Ladd Stock Farm of Yamhill, Oregon, by the advice of Mr. H. E. Dosch, then Secretary of the Oregon Horticultural Society, purchased from the late Felix Gillett, Nevada City, Cal., and planted quite a number of young walnut trees which are now in bearing. The first few years their cattle received first attention and the young trees were not cultivated as much as they should have been to make good growth. They therefore do not grow the quantity of walnuts they would have produced with better cultivation. Two or three years after this Mr. Z. T. Davis, of Dundee. Oregon, also by advice of Mr. Dosch, purchased of Mr. Gillett some 500 one-year-old seedlings. One year later the writer, who had some land adjoining $\mathrm{Mr}$. Davis, also became interested and set ont about 1,500 additional trees, and about two years later purchased the place belonging to Mr. Davis. and became owner of the young trees at Dundee, with the exception of a few purchased by several neighbors. All are now in bearing.

"Those who do not know the facts are inclined to give the writer more credit than he is entitled to. Mr. Dosch, the Ladds. Mrr. Davis and Mr. Gillett were first to interest themselves and should receive the credit to which they are entitled.

"We have now in Oregon and Washington quite a few trees in bearing, and we believe they can be grown here with profit. There is much to learn. We find the young trees should be carefully set out and receive good cultivation for the first few years. That the selection of the trees and the location in which to grow them are very important. The number of trees to the acre, and whether to grow seedling or grafted trees; and if grafted whether root grafting or top grafting is best must be considered.

"I think growing of walnuts has the advantage of many other products. The crop is easily grown, harvested and marketed; the labor greatly economized and the net profits a larger per cent of the gross receipts; while sometimes with other crops the results are just the reverse-the net profits but a small per cent of the gross receipts.

"The question is often asked how much is land worth that is suitable; how long before trees will bear, and how much will they produce. etc. The price of land depends largely on location; generally it is worth from $\$ 50$ to $\$ 150$ per acre. Seedling trees come into bearing firom 7 to 9 years of age, quantity from 10 to 50 pounds per tree; number of trees per acre, 20 to 40 . 


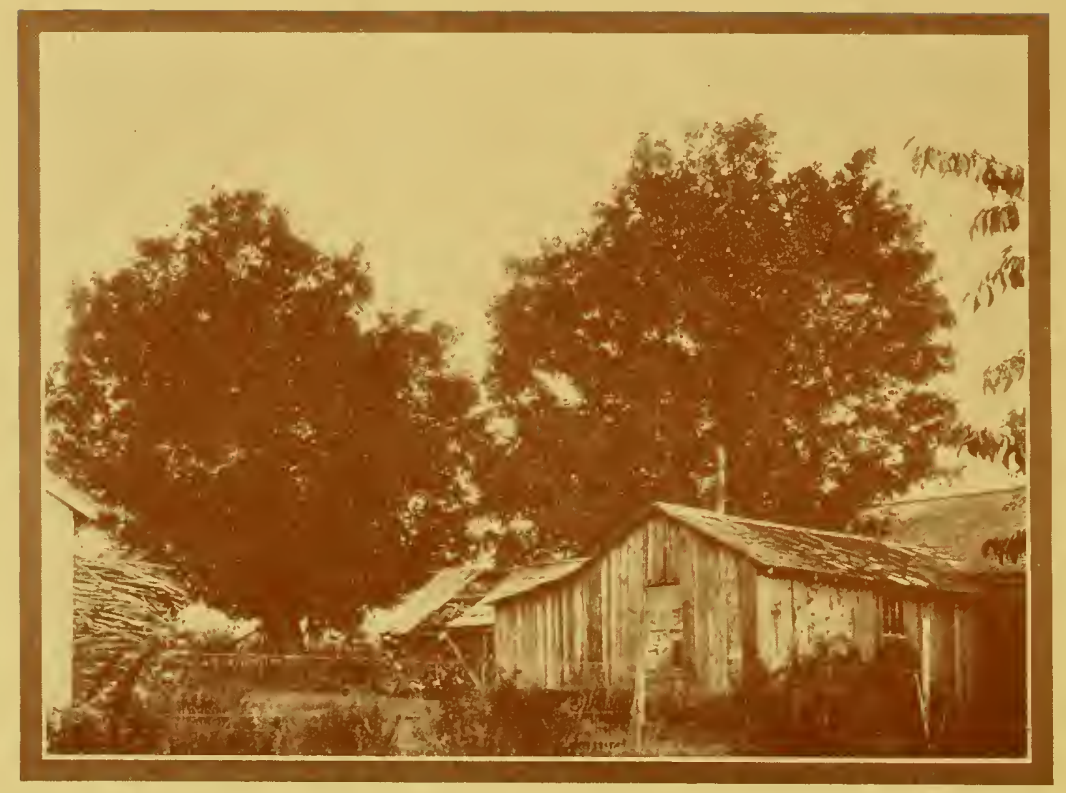

Sixty Year Old Walnut Trees on Derr Place

These trees are about 60 years old and were planted by I. M. Johns, who took the donation claim two miles southeast of McMinnville, about 184t, now the Derr farm. The trunk of the largest one on the right is $\mathbf{1 0}$ feet in circumference. and is probably the largest English walnut tree in Oregon. They have some nuts every year, but are shy bearers, due no doubt to lack of: proper pollination. The nut is not large, but is full of good meat and resembles the Parry. The trees are about two hundred yards from the Yamhill river, are hale and hearty and seem good for a few centuries. In fact, all of the seedlings examined in this county are healthy and vigorous.

There are half a dozen or more walnut trees growing in the woods and about the garden of Mr. J. T. Jones, seven miles west of McMinnville, which are a valuable study to the walnut grower. They are seedlings from the Casey tree, and they all bear full crops every year. The largest is 21 inches in diameter. One of them has a much larger and finer nut than that grown on the Casey tree. Hardpan is reached about 18 inches below the surface, which would indicate that no tap root were needed were it not for the fact that a tiny brook runs down throngh the garden not far from the trees. 


\section{WALNUT GROWING IN OREGON}

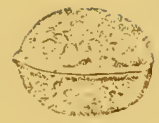

Following is the testimony of Col. Hemry E. Dosch, taken from "Better Fruit" of August, 1908:

"It is over twenty years since I first experimented with nut culture, more especially English, or, more properly speaking. French walnut culture, and by persistent effort in keeping this matter before the horticulturists am more than gratified to know that this important industry is at last receiving the attention it deserves: and a few who took my advice in the beginning and planted on a commercial basis are now reaping the benefit, as their products command the highest price in the market.

"First generation nuts are produced on original trees, or on trees grafted from the original trees. Those nuts when planted prodnce second generation trees, and the nuts from these serond generation trees are a little larger than the original or first generation. which is due to the pecmliar soil and climatic conditions of the Pacific Northwest, so well adapted to nut culture. Trees grown from second generation nuts retrograde very rapidly, producing nuts not half so large as even the first generation trees. and finally ruming out altogether. Ilence it is very essential that we plant nuts from the original trees, or trees grown from the original nuts or grafted from the original trees.'

A tree on John E. Brooks' claim, Casey Place, is one of the earliest and most important trees in the country. It has borne a good crop every year for thirty-five years, and in all that time has led a stremuous life. It was planted first in Portland from a nut supposed to have been brought from the Rhine in Germany by a German sea captain. It was broken down by stock when Amasa Brooks saw it, and with the consent of the owner transplanted it to its present site, on the side of a red hill a few rods above the house and about 100 feet above the level of the valley. There it was much abused by stock, and exposed to other acridents. When it began to bear, the squirrels would gather the nuts as soon as they were big enough to attract them. When the tree was visited in August, 1909, for the purpose of getting a photograph it was found that a squirrel had burrowed under the roots, making an opening large enough to admit a goodsized foxhound. and a quantity of muts hulls were piled about it and scattred beneath the tree. It is 23 inches in diameter and has a branch spread of nearly 60 feet. Trees of the fourth generation from this tree are in bearing near Mc.linnville and are producing fairly good nuts, some better than the original tree. demonstrating that the seedling walnut tree can be improved here by seed selection. 


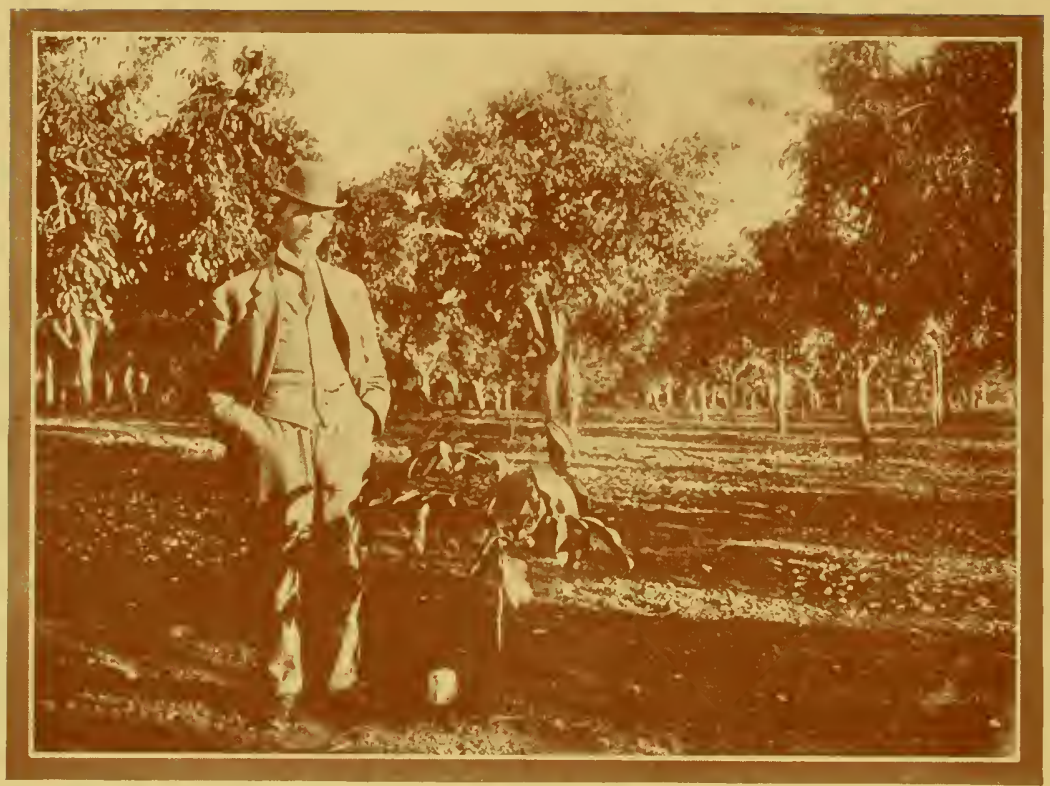

A Grafted Halnut

The above is a two-year-old grafted tree in the orchard of Mr. Prince. It was sent to him by Judge Leib, of San Jose, in order to convince him of the superiority of the grafted tree. You will note that the little bush has two good-sized nuts, and also that it bore one last year, the first year from the nursery. With the ratio of increase at 20 years of age it would produce about three and one-quarter tons of walnuts, comting 42 nuts to the pound, the weight of first-class Oregon walnuts. But this is not probable.

\section{GRAFTED TREES}

The testimony in favor of the grafted tree is not yet very abundant in Oregon, as the grafting business is new; but with the evidence at hand it will smely have a standing in court.

Prof. Lewis speaks plainly on this subject. He says:

"One of the main points of discussion is, Which are preferable - grafted or seedling trees? Let us cnnsider the seedling tree first. There are men who claim that these are superior to grafted trees, especially in size. prolificness, etc.; that there is something about our wonderful Oregon climate that causes the so-called second generation trees to bear larger and better fruits than the parent plant. And these writers love to dwell on the subject of 


\section{WALNUT GROWING IN OREGON}

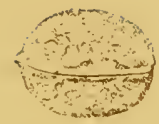

generation. There is at times a sort of mystery, an uncanny ragueness connected with this subject that is baffling and bewildering to the layman, and causes him to listen with mouth agape. It is the same sweet sily story that we have had to learn by bitter experience with other nuts and fruits, and some of us will evidently pay dearly for it in the case of the walnut. The term 'first generation' is generally applied to the parent treesome say the original tree, while others put the clanse on the original grafted tree. Nuts taken from such trees and planted prodnce the second generation trees. These may be equal, may be superior, or may be inferior to the original stock. It is this very variation and unstability that makes the seedling to a more or less degree a gambling proposition."

The following is taken from a paper on walnut culture by Luther Burbank, read before the annual meeting of the California Fruit Growers convention :

"In all cases the best results will be obtained by grafting on our native California black walnut or some of its hybrids. No one who grows English walnuts on their own roots need expect to be able to compete with those who grow them on the native black walnut roots, for when grown on these roots the trees will uniformly be larger and longer lived, will hardly be affected by blight and other diseases, and will bear from two to four times as many nuts, which will be of larger size and of much better quality. These are facts, not theories, and walnuts growers should take heed.

"Although not popular among nurserymen, yet the best way to produce a paying orchard of walnuts is to plant the nuts from some vigorous black walnut tree, three or four in each place where a tree is to stand. At the end of the first summer remove all but the strongest among them. Let the trees grow as they will, for from three to six years, until they have formed their own natural, vigorous system of roots, then graft to the best variety extant which thrives in your locality, and if on deep, well-drained land you will at once have a grove of walnuts which will pay, at present, or even with very much lower prices, a most princely interest on your investment. By grafting in the nursery, or before the native tree has had time to produce its own system of roots by its own rapid-growing leafy top, you have gained lit- 


\section{WALNUT GROWING IN OREGON}

tle or nothing over planting trees on their own roots, for the foliage of any tree governs the size, extent and form of the root system. Take heed, as these are facts, not fancies, and are not to be neglected if you would have a walnut grove on a safe foundation.

"I hold in my hands a record, and also a photograph, of one of the Santa Rosa walnut trees, grafted, as I recommended, on the black walnut, 1891; this was handed to me by the owner, George C. Payne, of Campbell. The record may be of interest to you: Dimensions (1905)-Spread of top, 66 feet; circumference one foot above gromnd, 8 feet 9 inches. No record of nuts was kept until 1897, which amounted to 250 pounds; 1898, 302 pounds; 1399, 2.29 pounds; 1900, 600 pounds ; 1901, 237 pounds ; 1902, 478 pounds; 1903, 380 pounds; 1904. 481 pounds; 1905, 269 pounds; 1908, 712 pounds.

"The walnut has generally been considered a very difficult tree to graft successfully. Mr. Payne has perfected a mode of grafting which in his hands is without doubt the most successful known; by it he is uniformly successful, often making one hundred per cent of the grafts to grow. Who can do better by any method?

"When you plant another tree, why not plant a walnut? Then, besides sentiment, shade and leaves, you may have a perennial supply of nuts, the improved kinds of which furnish the most delicious, nutritious and healthful food which has ever been known. The old-fashioned hit-or-miss nuts, which we used to purchase at the grocery store, were generally of a rich, irregular mixture in form, size and color, with meats of varying degrees of unsoundness, bitter, musty, rancid, or with no meat at all. From these early memories, and the usual accompanying aftereffects, muts have not heen a very popular food for regular use until lately, when good ones at a moderate price can generally, but not always, be purchased at all first-class stores.

"The consumption of nuts is probably increasing among all civilized nations today faster than that of any other food, and we should keep up with this increasing demand and make the increase still more rapid by producing nuts of uniformly good quality. This can be done without extra effort, and with an increase in the health and rapid and permanent increase in the wealth of ourselves and neighbor's." 


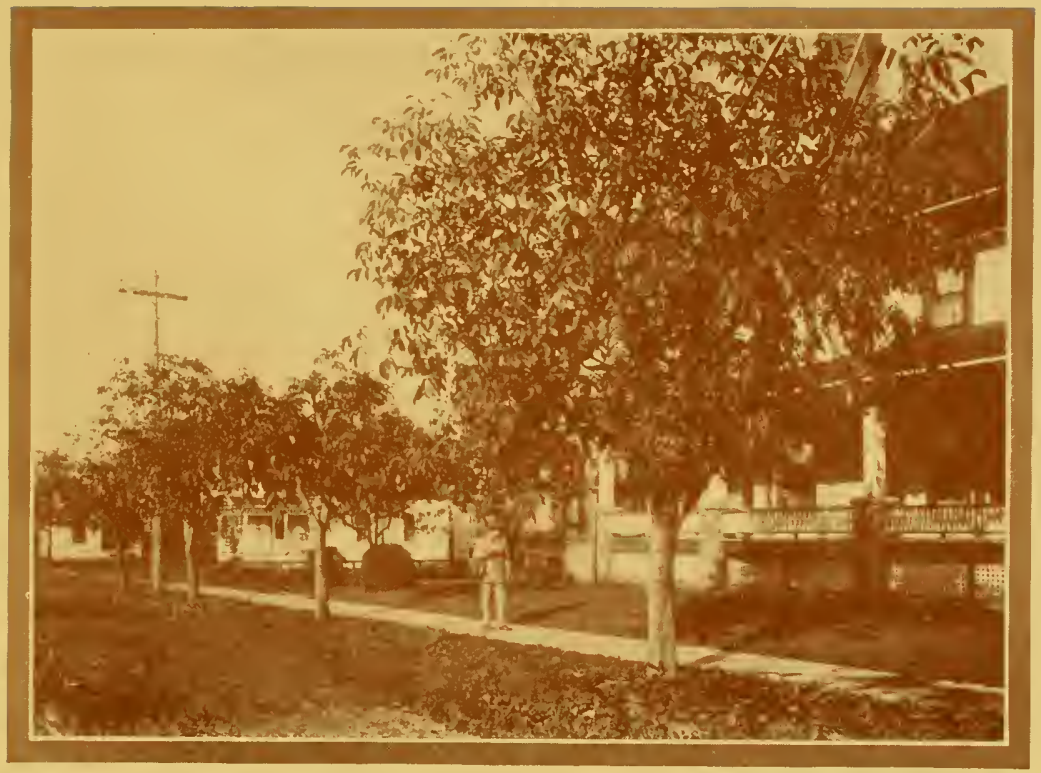

Row of Eleven Year Old Top Grafted Black II alnut Hybrids

An American black walnut growing on a lot on the east side of Grant street, residence of J. C. Cooper, McMinnville, grafted by Mr. Payne May 14, 1908, grew 7 1-2 feet in 95 days and was still growing when the terminal buds were nipped by the early September frost of that year. The sprouts were pruned back to 12 inches. The tree made a vigorous growth in 1909, making a spread of 13 feet. Some think the American black a better tree for grafting stock that the California black. One of the noblest and grandest trees in any American forest is the American black walnut, and while a little slow at the beginning of its career it is only a question of time when it will overtake all others. It knows no disease or pests, and he who plants it lays a foundation for 20 to 50 generations to come as well as for himself and those of his own household.

A four-year-old hybrid, 4 inches in diameter, grafted in by Mr. Payne, grew a sprout as shown, 7 feet 9 inches high in four months from the setting of the graft. It is growing on the east side of D street near the Presbyterian church in front of the residence of Mrs. Sarah Lpdegraf, McMinnville, Oregon. Three trees there all show the same vigor, with little or no cultivation. 
John H. Hartog. formerly of Eugene, wrote of the experience of Mr. E. Terpening, one of the most successful walnut growers near that city:

"Mr. Terpening is a devotee of the grafted tree. And why? A burnt child spurns the fire, says the proverb. Mr. Terpening set ont second generation Mayettes and Franquettes, expecting that these seedlings would produce true, but when they commenced to bear, behold his amazement at finding that he had a variety of almost every kind. This was enough to convince him that in the future he would use grafted trees, and know what he was doing and what kind of nut he was raising.

"Counting out trees of other kinds, he has four acres in walnuts, and these produced-
In $1905 \ldots \ldots \ldots \ldots \ldots \ldots \ldots \ldots$. 700 pounds
In $1906 \ldots \ldots \ldots \ldots \ldots \ldots \ldots \ldots \ldots$ pounds
In $1907 \ldots \ldots \ldots \ldots \ldots \ldots \ldots$. 2000 pounds
In $1908 \ldots \ldots \ldots \ldots \ldots \ldots \ldots \ldots$ pounds

"This spring he set out 450 more trees and wisely he put them 50 feet apart and will grow peaches in between for a few years. While it is generally said that walnuts come into bearing after 8 years, Mr. Terpening states that the grafted tree will bear commercially in 6 years, which tallies exactly with my experience.

"The Terpening walnut trees are grafted on American black and his favorite variety is the Mayette and lately the so-called Improved Mayette."

\section{WALNUT GRAFTING}

Walnut grafting is in a class by itself. and walnut budding is not a success as practiced at the present time, although the ordinary method is shown in the cut. The top grafting method shown is easy and sure if you have "the know-how and skill." One of the important things to remember in tree surgery as well as other kinds. is to work quickly and deftly. Don't let the wounds of the scion or stub remain exposed longer than necessary. Make the cuts smooth with a very sharp knife, kept sharp by frequent "stropping." Expert walmnt grafters are few, but the ordinary skillful orchardist or amateur can do fairly successful work by a study of the drawings in "Details of Walnut Grafting" on next page. and using common sense methods. 


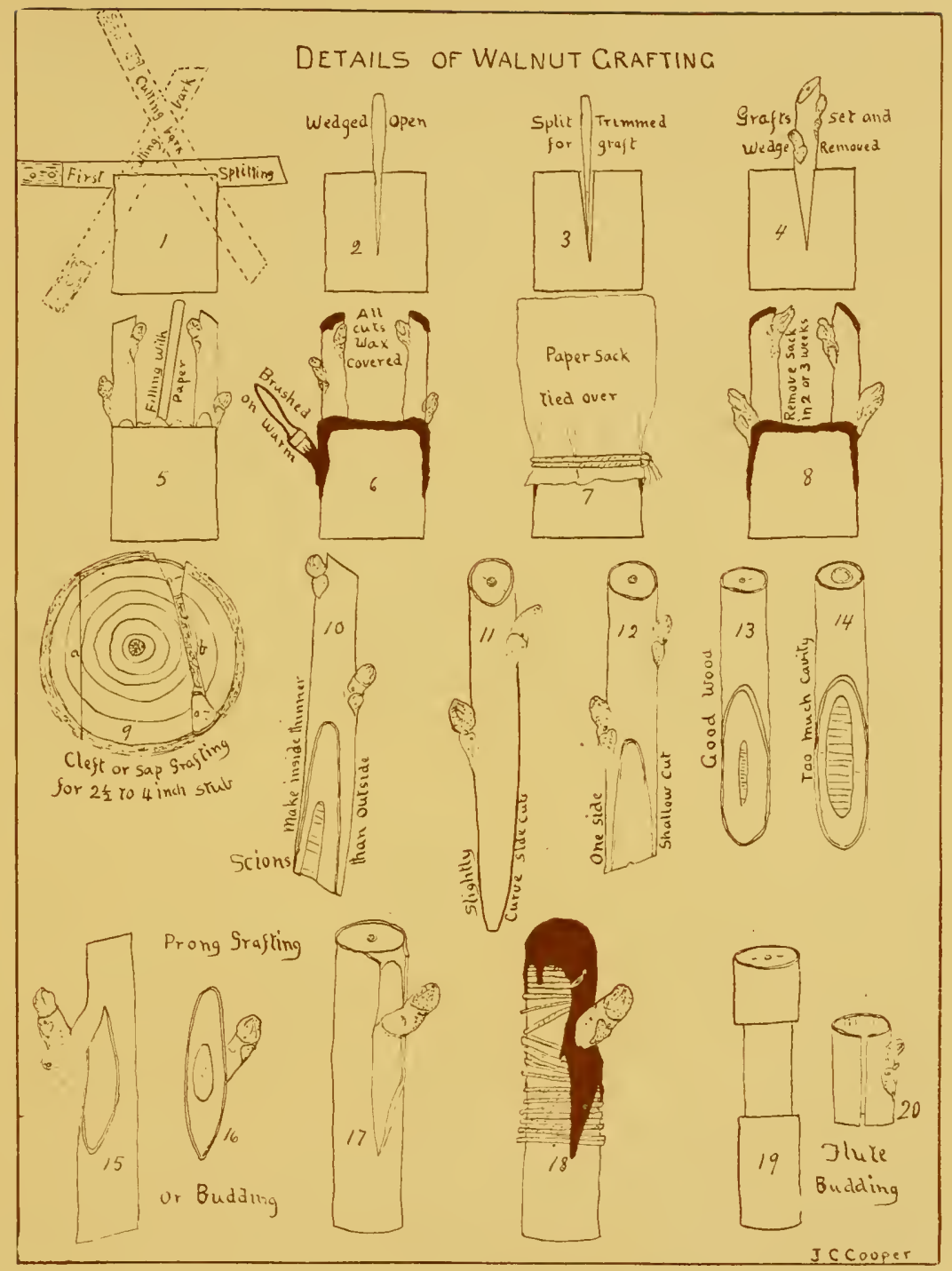

Cut off the branch or stock to be grafted with a sharp pruning saw at a point where the stump will be from one to two and a half inches in diameter. Split through the center of the stub with a sharp knife as shown in figure 1, using a mallet. Depress the point of the splitting knife and strike with the mallet, cutting the bark and sap down the side of the stub instead of tearing it then depress the handle and eut down the other side in the same way. 


\section{WALNUT GROWING IN OREGON}

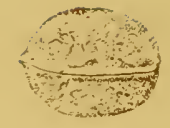

Open the split slightly with a hardwood wedge, as in figure 2. Slightly bevel the split, cutting upward, with a sharp knife as in figure 3. Insert the carefully fitted scion as at figure 4 . being careful to have the cambium layer, the inner layer of the bark, of both stub and scion come together.

When the scion is carefully fitted remove the wedge and fill the split with paper as shown at figure 5. Then cover all wounds over with wax brushed on warm as at figure 6 . The melted wax should be about the consistency of thick honey. Tie a paper sack over all as at figure 7 . This should remain until scions begin to grow. It keeps them warm and prevents drying out by hot winds. In from ten days to three weeks the scions will have started sufficient to gradually remove the cover as at figure 8. In eight or ten days from the time grafts are set a small opening should be cut or torn in the north side of the paper sack so that the sprouting buds may have air and their growth noted.

When the stock is too large to split through the center it should be split to one side of center as shown in figure 9. The method of shaping the scions is shown in figures 10, 11 and 12 . Good scions and poor are sown in 13 and 14 . Scions with buds not too far apart are best. Prong grafting is shown in figures 15 to 18 , and finte budding in 19 and 20 .

In grafting the stock should not close on the scion with sufficient force to bruise or injure it, but just tight enough to hold.

Scions should-be of last year's wood and pruned or cut from the trees in late winter, when the tree is dormant, and cut into about 12-inch lengths, long enough to make three or four grafts. Select upright wood. Drooping branches make a sprawling and sometimes a barren tree.

The dormant scions should be packed away in a cool, dark cellar in damp sand or moss, or put in cold storage and kept dormant until ready for use. Do not allow the buds to swell. It will be well to look at them occasionally to see that they do not get too dry nor be so damp as to mold.

In the spring when the sap is well up and the trees to be grafted have sprouted and are growing during April and May the grafting should be done. Work may be continued even after the catkins are out and the leaves half grown.

The methods described are those practiced by Mr. George C. Payne, probably the most successful walnut grafter in the business. 


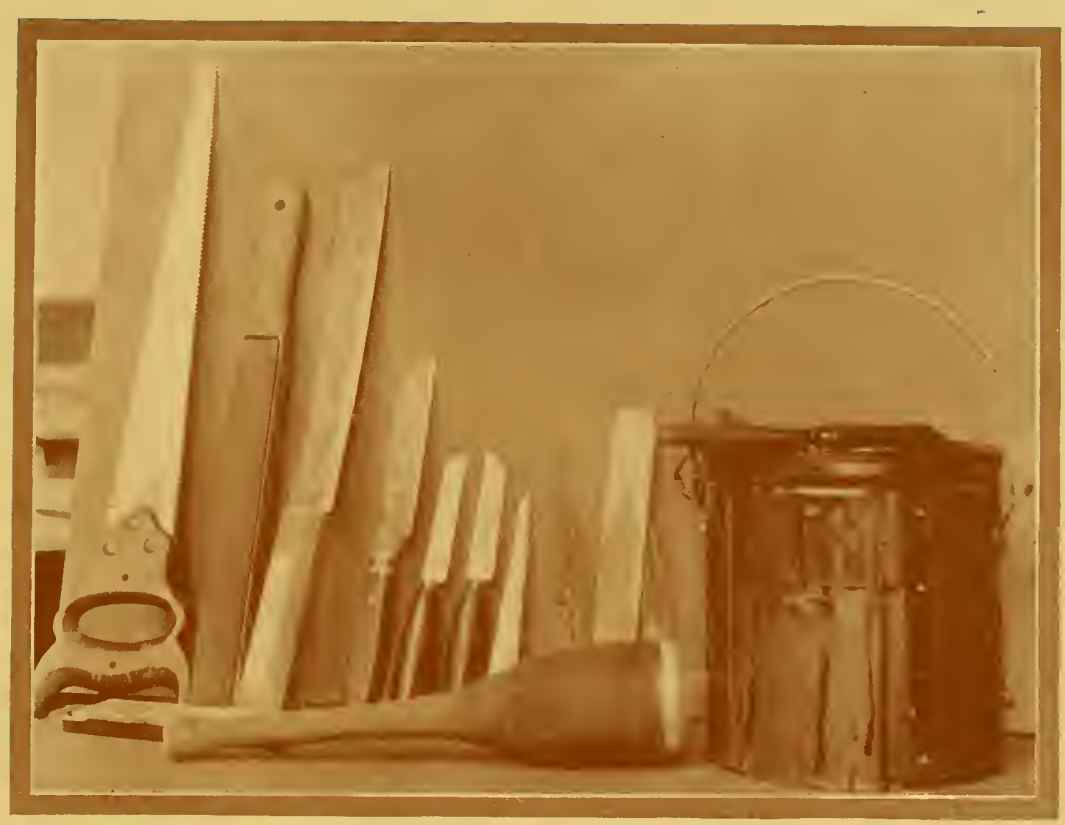

Tools $L^{\top}$ sed in IValnut Grafting

Plate One. Furnished by Oregon Agrieultural College

\section{GRAFTING WAX}

The following formula is the grafting wax used by Mr. Payne:

Rosin, 5 pounds.

Beeswax, 1 pound.

Finely pulverized chareoal, 1-2 pound.

Raw linseed oil, 1 gill.

Be sure that the charcoal is finely pulverized. First melt the beeswax and rosin, being careful not to have the fire too hot. Add the charcoal, stirring constantly, and then add the oil. Mould into bricks by pouring into greased pans. When desiring to use break off a few lumps and melt in such a contrivance as is shown in the plate of grafting tools. The wax must be quite liquid if applied successfully.

Nursery grafting, or root grafting, is not a suceess as practiced at present. The best grafters do not succeed with more than 10 to 15 per cent. This makes the grafted tree cost from $\$ 1.50$ to $\$ 2.00$ per tree, and makes that kind of walnut planting expensive. However, Col. Dosch, in his article, quotes Professor 


\section{WALNUT GROWING IN OREGON}

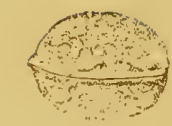

Leckenby, the noted agrostologist, as saying that if directions are religiously followed ninety per cent of the grafts will grow. The directions are as follows:

"For walnut grafts on scions use nne gallon of water with four teaspoonfuls of sulphate of quinine. Cut scions submerged in the solution, and wash the cut on tree at once, to prevent it from turning black, acting as an antiseptic; then insert the scion as on other fruit trees."

This, from such authority, is worthy of a trial. A great amount of experimenting has been done in walnut grafting and a way to success will be found.

\section{BEST STOCK ON WHICH TO GRAFT}

Mr. Burbank, Judge Leib, and George C. Payne, all of California, think the California black or some of its hybrids make the best stock in California. Mr. Groner prefers the hybrid for Oregon.

Mr. A. McGill, of Oregon, thinks that neither the California black nor its hybrid are suited to this climate. Few have harl more experience, costly experience at that, than Mr. McGill. He thinks the American black better for Oregon.

It is sometimes asked, why not plant seedling walnuts and top work those that are not good bearers? Because the grafts will not do so well on the English stock as on the black; and it is also found that the English stock does not make as good a foundation as the black.

Therefore, the best growers in Oregon conclude that the seed from a thrifty American Black, or close hybrid, is best for this state. In three or four years after planting cut off the truuk about as high as a man's waist or shoulder and put in the graft from the best variety available. The third year from setting of the graft you will have a crop of nuts.

Mr. Payne can set 250 to 300 grafts in a day. His wages are $\$ 8$ a day, and he furnishes the wood. So you see that your trees would cost very little. Good black walnut seed can be had very cheap, probably at a cost of 50 cents to $\$ 1$ per bushel, the Oregon product prefered.

Some of the California hybrids make rapid growth, but too rapid growth of wood niay not be desirable. It may mean early maturity and early decay, and too few walnut bearing boughs. 


\section{WALNUT GROWING IN OREGON}

\section{GOOD PLAN FOR WALNUT ORCHARD}

Mr. Prince, of Yamhill county, has modified his views somewhat in regard to the grafted and seedling trees. He thinks that possibly the permanent orchard shonld be of the grafted variety, possibly on the Royal or California hybrid of rapid growth. He

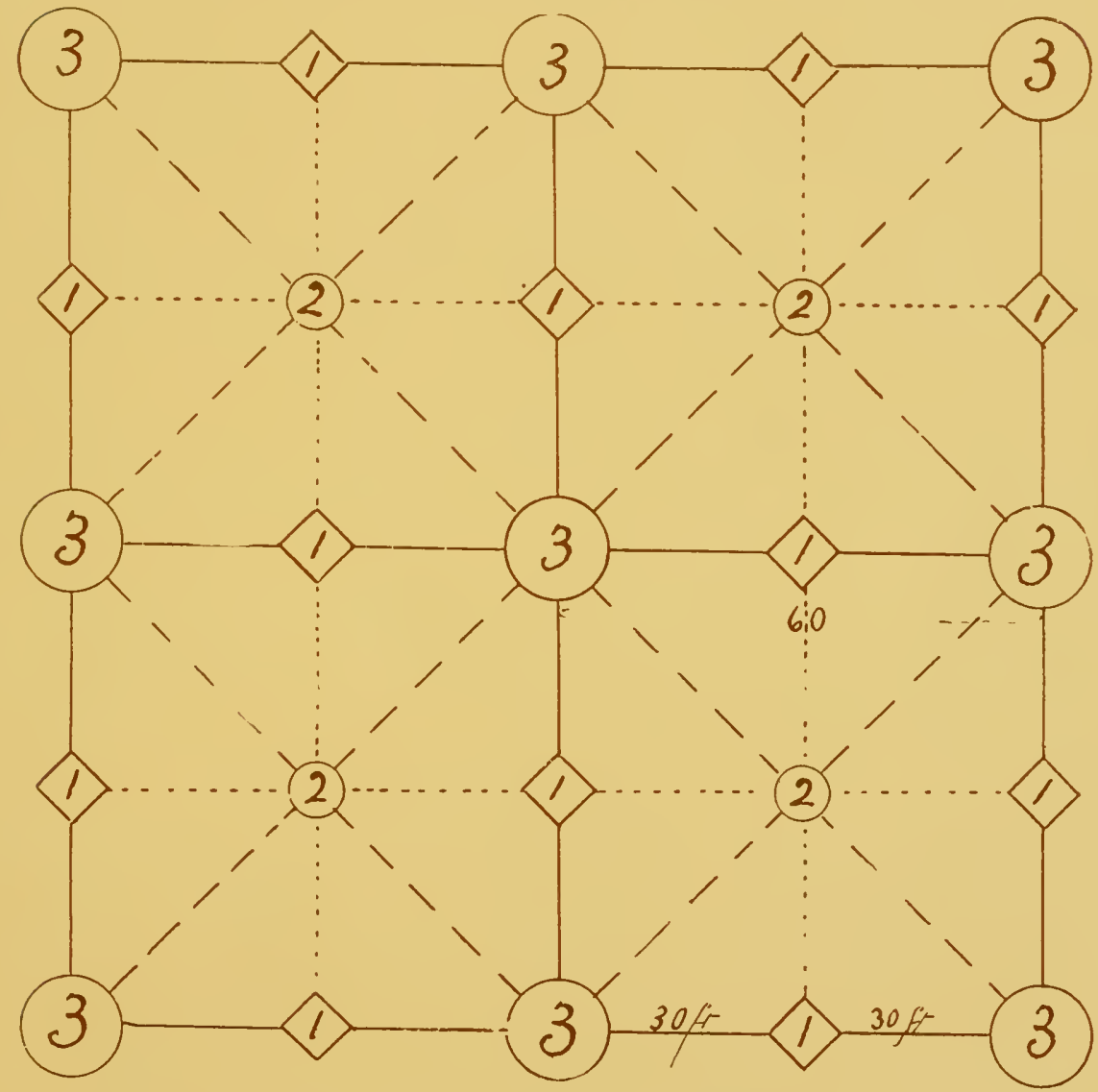

proposes the above form of an orchard. The principal grafted trees should be placed in square form 60 feet apart, represented by figures 3. In the center of these squares at figures 2 he would either plant the same trees or some other seedling variety which will bring the trees about 42 feet apart. Nidway between the main grafted trees be would plant other trees, or apple trees, rep- 


\section{WALNUT GROWING IN OREGON}

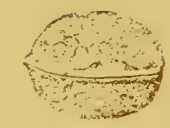

resented by figures 1 in the little squares. This would make trees 30 feet apart. At the end of 15 or 20 years, when the trees possibly beeome cromed. he would remove the No. 1 trees. If this were an apple tree, it would already have served its best days and no great loss would be had by its removal. At the end of 25 or 30 years we would remove No. 2, if the trees became crowled, leaving a permanent orehard of trees 60 feet apart. 12 trees to the acre. This is an excellent arrangement. and no doubt about the best that has yet been proposed for walnut eulture in Oregon.

It is best to plant in square form. a tree to the eenter of each square, forty to sixty feet apart is the rule. Berries, small fruit. potatoes, vetch, peas, beans, ete., can be grown between the trees while they are young, leaving six or eight feet free to be cultivated each side of the trees.

Many plant apples, peaches, prunes or cherries between walnut trees, planning to cut them out when the latter are of such size as to need all the space.

These elops between the rows produce an income during the eight years' waiting for the walnuts to come into bearing. Each grower must decide this point according to his situation, always avoiding grains and grasses.

\section{THE TAP ROOT}

Some experimenting has been done and much speculation has been indulged regarding the tap root. One writer disposes of the whole subject in this manner:

"The cutting of the tap root in planting seedlings has been a question for much discussion, many growers formerly holding that to eut it meant to kill the tree. This has proved a mistake. It has been practically demonstrated that the tree thrives better with the tap root eut if properly done with a sharp instrument, making a clean cut. New growth is thereby induced, the abundance of lateral roots feed the tree more satisfactorily and the trees come into bearing from two to three years earlier than would otherwise be the case." 


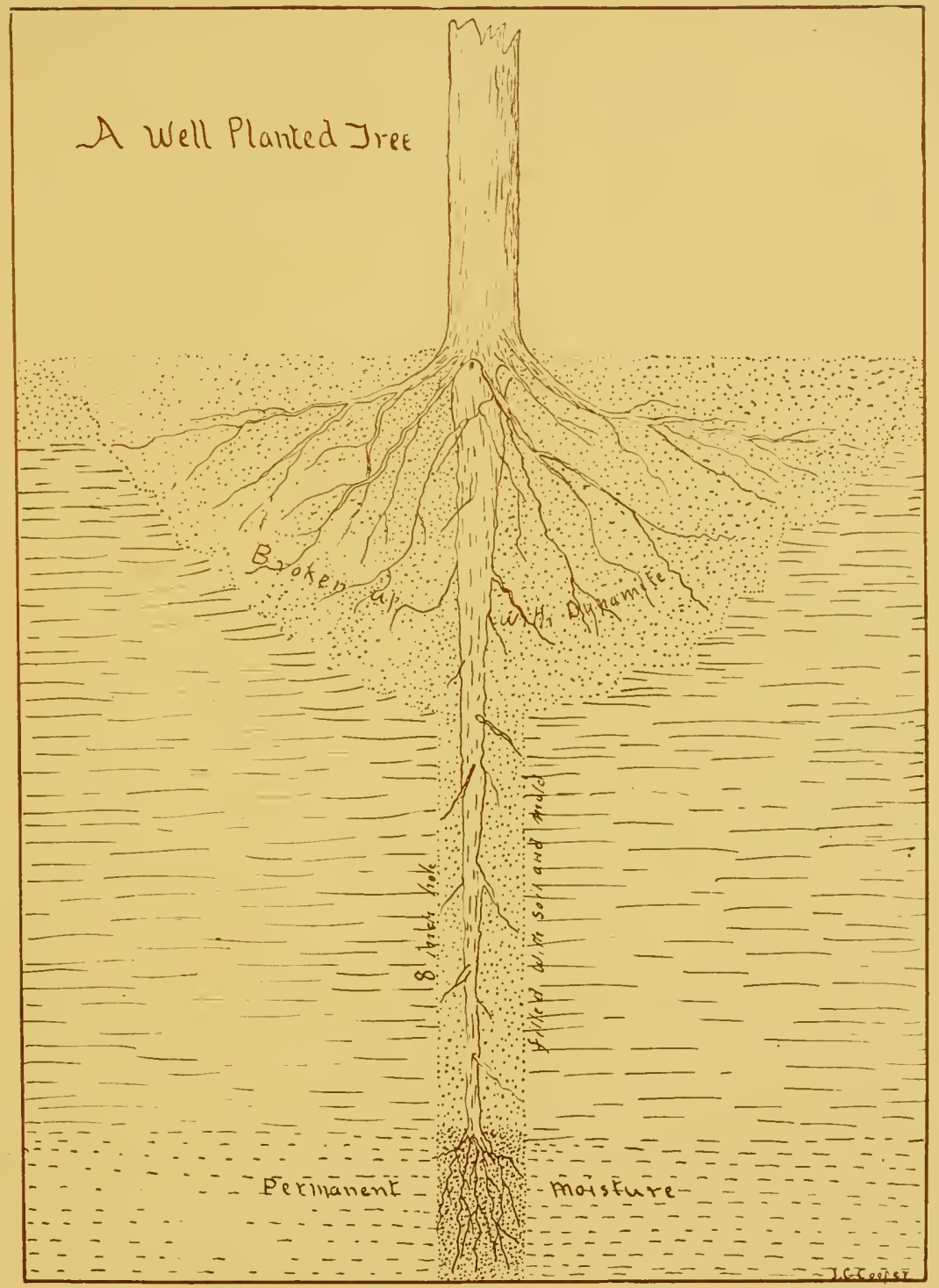

Before accepting this as final it would be well to make further inquiry. The summers of western Oregon are practically rainless and when the kernel in the formed shell is maturing unless there is irrigation a distress call is sent down to the roots for moisture, if the weather is very dry. The lateral roots cannot supply this dire need and if the main pump is not working away 


\section{WALNUT GROWING IN OREGON}

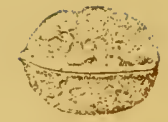

down deep in the moist earth the kernel will not fill well and may perish entirely. For this reason no fibre of the tap root should be disturbed, but rather eneouraged by a well auger hole, bored before the tree is planted, down to the reservoir of moisture that will not fail in the dryest season.

The moisture in a dry season as a rule is nearer the surfaee in the valley than in the hills and gives a better filled nut. In a wet season, when the ground everywere is full of moisture, the hills may produce a more abundant erop than the valley, but in the run of years it will require more time to prove which is most valuable for walnut eulture. Trees grow in either plaee. but he who euts the tap root in any soil does so at the peril of his erop in dry seasons.

Of the taproot, Wm. M. Reece, of the firm of Epps, Reeee \& Tillmont, Eugene, Oregon, writes:

"The peenliar climatic eonditions of the Willamette Valley, which at a eertain season of the year becomes semi-arid, fully justifies the statement that trees not having a tap root are annually eheeked in their growth when irrigation is not used; while those that do have a tap root, as do walnuts, continue to grow and thrive even in the driest weather. The walnut should be planted, however, in soil having a subsoil free from any hard substance that will permit the tap root to grow downward into the strata of perpetual moisture.

"This has been most thoroughly demonstrated in our walnut orehard this, the driest year in the memory of old settlers in the Valley.

"When the growth of our apple, cherry and peach trees ceased becanse of the dry weather, our walnuts kept on growing as if supplied by eontinuous rains. It is true that liberal cultivation through the dry season will materially aid the growth of all kinds of trees not having a tap root and is indispensable to the growth of young walnut trees, trees that have not extended their tap root down to perpetual moisture.

"Walnut trees, in the opinion of the writer, cease growing upward when they eease growing downward: that is to say, when rock. shale or impenetrable hardpan stops the growth of the tap root, the tree has practically reaehed its height.

"Therefore, in planting a walnut grove. borings should be made to test the depth of the soil and character of the subsoil. 


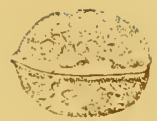

"Unquestionably the best variety for this climate is the Franquette and next the Mayette.

"Grafted trees are to be preferred to seedlings. Grafted trees bear much sooner and the fruit is more uniform in size, though a seedling that has attained the bearing age will produce as much fruit as a grafted tree of the same age; this we have occasion to observe from comparisons in our own orehard.

"We have trees 14 years old that bore 100 pounds at the age of 12 years and the product sold for $25 \mathrm{c}$ a pound for planting purposes.

"Those who had the misfortune to have the tender shoots of their walnut trees killed by the umusual frost early last May, should not be diseouraged. Just examine the limbs now and you will find that three or four more shoots grew out where the one was killed. This makes more fruit buds for next year and the shortage of crop this year will be more than made up next.

"The writer believes that walnut growing will prove to be the nost profitable industry in the Willamette Valley.

"WM. M. REECE."

It seems to be a characteristic of the walnut and hickory, and possibly other nut trees, to send down a tap root deep into the earth to draw up the distilled and purified moisture that has been refined and sweetened in the lower depths. The older boys of the Middle Western states can recall the time when they wandered through the woods in late winter time, with a long pole or rail on their shoulders with which they "pulled hickory root." The young sprout was "withed" around near one end of the pole, then all hands put their shoulders under the long end and with an "altogether, heave, oh," draw up a tap root 4, 6 and 8 feet long. The lowest end was the choicest and sweetest. It was delicious and in the division of a day's hunt some of these found their way to "his best girl" at sehool.

Whether the water down in these lower depths possesses these qualities, and that they are necessary to give the Oregon walnut its superiority is yet a matter of speculation, but that these conditions exist is well known and should have fullest consideration by the intelligent walmut culturist. 


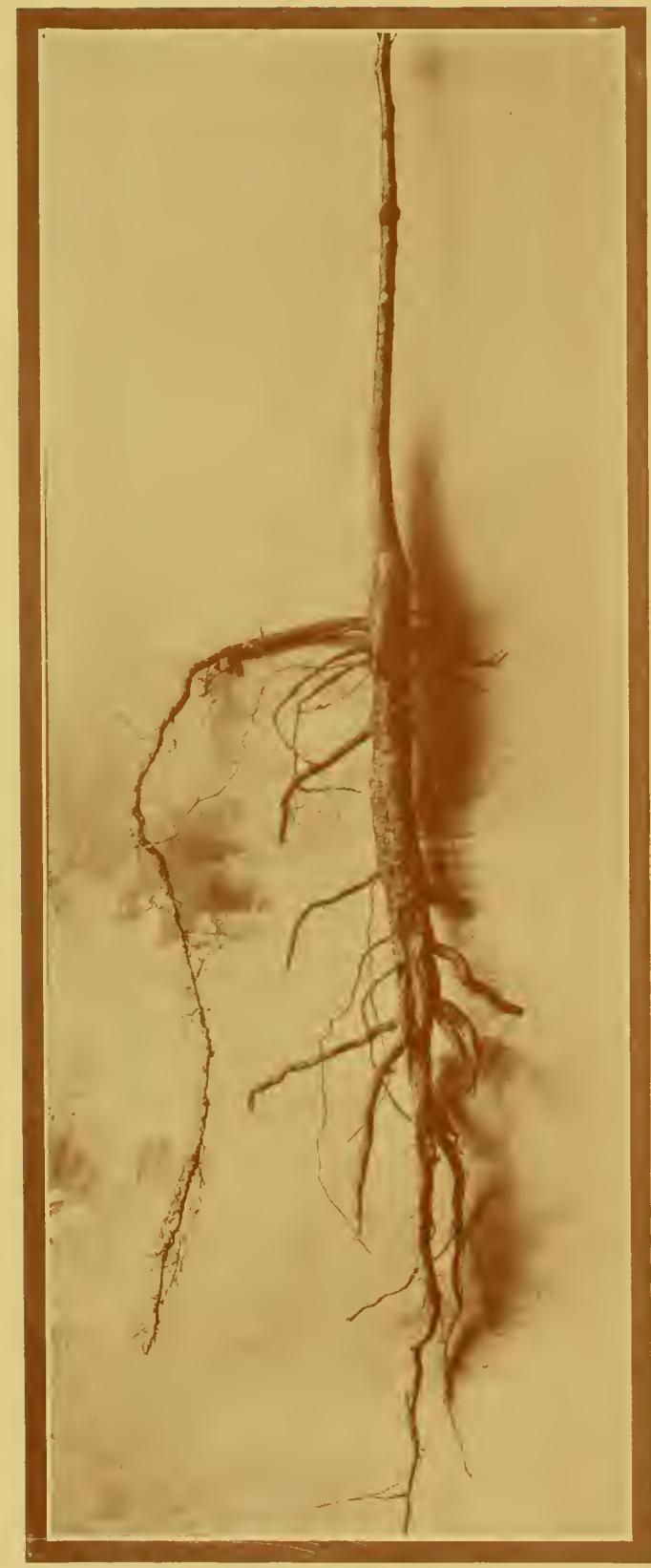

Tap Root of a Two-year-old Black II alnut showing how the root grou's dow'n to permanent water level, thus insuring full crops regardless of weather conditions
Cut of tap root of a 2-year-old American Black which grew in the lower red hill land of $\mathrm{Y}$ a $\mathrm{m} \mathrm{h}$ ill County. There is but one lateral root near the surface and this was probably caused by the tap root striking harder soil on its way down to permanent moisture level.

This tap root is 3 feet long and nearly 6 inches in circumference. It is one of the best object lessous to be had in walnut ("ulture in Oregon.

Though the Willamette Talley has practically four rainless months of sunshine. irrigation is unnecessary. There is no other country comparable to it. Its cool and $d$ e w y summer nights, together" with its great subterranean reservoir supplied by the winter rains, are the reasons why its crops never f a i l a n d w h y it s fruits fill "red, round and luscious," a n d why the walnut has so persistently shown it s preference for this favored region. 


\section{WALNUT GROWING IN OREGON}

\section{WALNUT CULTIVATION}

While the walnut is the hardiest of trees and in many cases has borne heavily in Oregon without cultivation, experience has proved that, like fruit trees, cultivation up to the tenth or twelfth years increases the growth, the yield and the quality of the product. After full maturity no further cultivation is necessary, the tree taking care of itself with the independence of any forest tree.

With a young grove it is best to plow between the rows after the rains cease in the spring, and then stir the ground occasionally all through the summer with the harow or disk; this holds the moisture. When some trees seem backward a trench should be dug some two feet or so away, and a couple of feet deep, filled with fertilizer and closed over. This will encourage hardier and more rapid growth. Lime can also be used witl good effect, it being customary in England to haul wagon loads to the walnut lands. Continually hoeing and digging constitute the best treatment, as one tree on the Prince place, a Mayette, has proved. It was given daily cultivation, by way of experiment, and more than doubled the size and yield of other trees of the same age not so treated.

\section{PRUNING WALNUTS}

Walnuts require very little pruning. However, to do well they must have plenty of light and air, and there must be room under the trees to cultivate. To this end, keep all lateral growths removed the first two years. pushing the strong terminal growth. Young trees so treated often make five or six feet in that time. They must be staked and tied with a broad strip of cloth. Cross the cloth between the stake and the twig so as not to bruise the tender wood. As the limbs begin to grow take out an occasional owe to prevent the tree becoming too thick. When large limbs are removed, cut on the slant, carefully waxing to prevent decay. Heading-in is often beneficial when the tree does not seem to be fruitful. Train the trees upward as much as possible.

In Roumania and some of the eastern countries of Europe, some of the walnut trees have such an enormous spread that a flock of five hundred sheep can lie in comfort beneath the shade of one tree and have ample room. If this vine-like tendency to spread can be obviated by intelligently training the trees upward, 


\section{WALNUT GROWING IN OREGON}

and its productiveness maintained or increased, the walnut grower of Oregon will have accomplished much in the conservation of our resources.

At present we can make a tree that will produce 500 pounds of walnuts in 25 to 30 years. With 12 trees to the acre, will give 6000 pounds of muts; two and one-half times that of wheat at 40 bushels per acre, and they will not require the expensive refrigerator cars and rapid transit of perishable fruits.

\section{TRAINING THE TREES}

It will only be necessary to train the limbs in seven or eight feet all round to be able to double the number of trees to the acre. Then train the trees skyward and increase the number of nut-bearing boughs, and the yield will be increased accordingly. If the nuts on the higher branches fill as well as on the lower, the tree can not he made to grow ton high, because we have no violent storms to throw down the trees, and the nuts are selfgathering. These and many other valuable and interesting problems in the industry are to be rorked out.

According to Prof. Lewis, who is good anthority, a later and better method is to cut the young tree back to 4 feet and make it throw out three or four laterals. When these laterals are fully grown, bind them up in a bundle one or two feet diameter with soft strands of rope. In the dormant season cut these laterals back to about two feet. This will multiply the branches. Cut back the new growths again the next year, and so on; this will greatly increase the nut-bearing boughs and will train the tree upward. This seems to be the most sensible method of pruming ret proposed.

\section{NO DISEASES INJURE OREGON WALNUTS}

The soft, moist atmosphere of western Oregon, so favorable to the English walnut, seems wholly unfavorable to pests that destroy the crop in other climates. A crop has never been lost or materially injured in Oregon through these sources: in fact, 


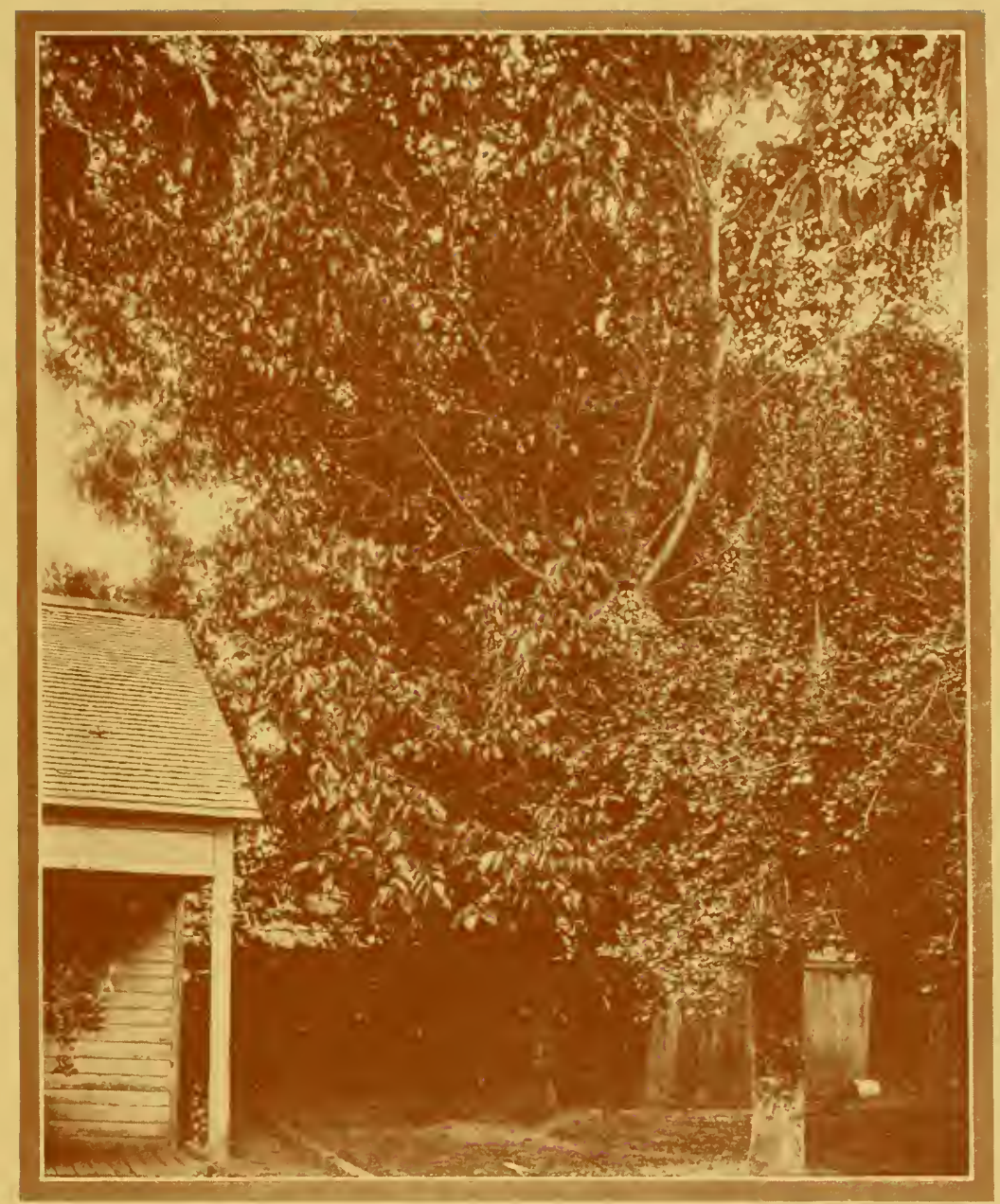

Old Halnut Trees Planted About 1950 . Near Mc.Minnmille, on the Y amhill Ricer

so free are the Oregon trees of such enemies that little thought or attention has been given to this phase of the subject. In a few localities where eaterpillars have attacked the foliage they have been quickly eradicated by an arsenic spray. Fumigating will kill insect life. A bacterial disease that has made its appearance in Califormia has not been seen in this state. Winter spray of lime and sulphur will kill moss and lichens, which are about the only parasites that attempt to fasten on Oregon walnut trees. 


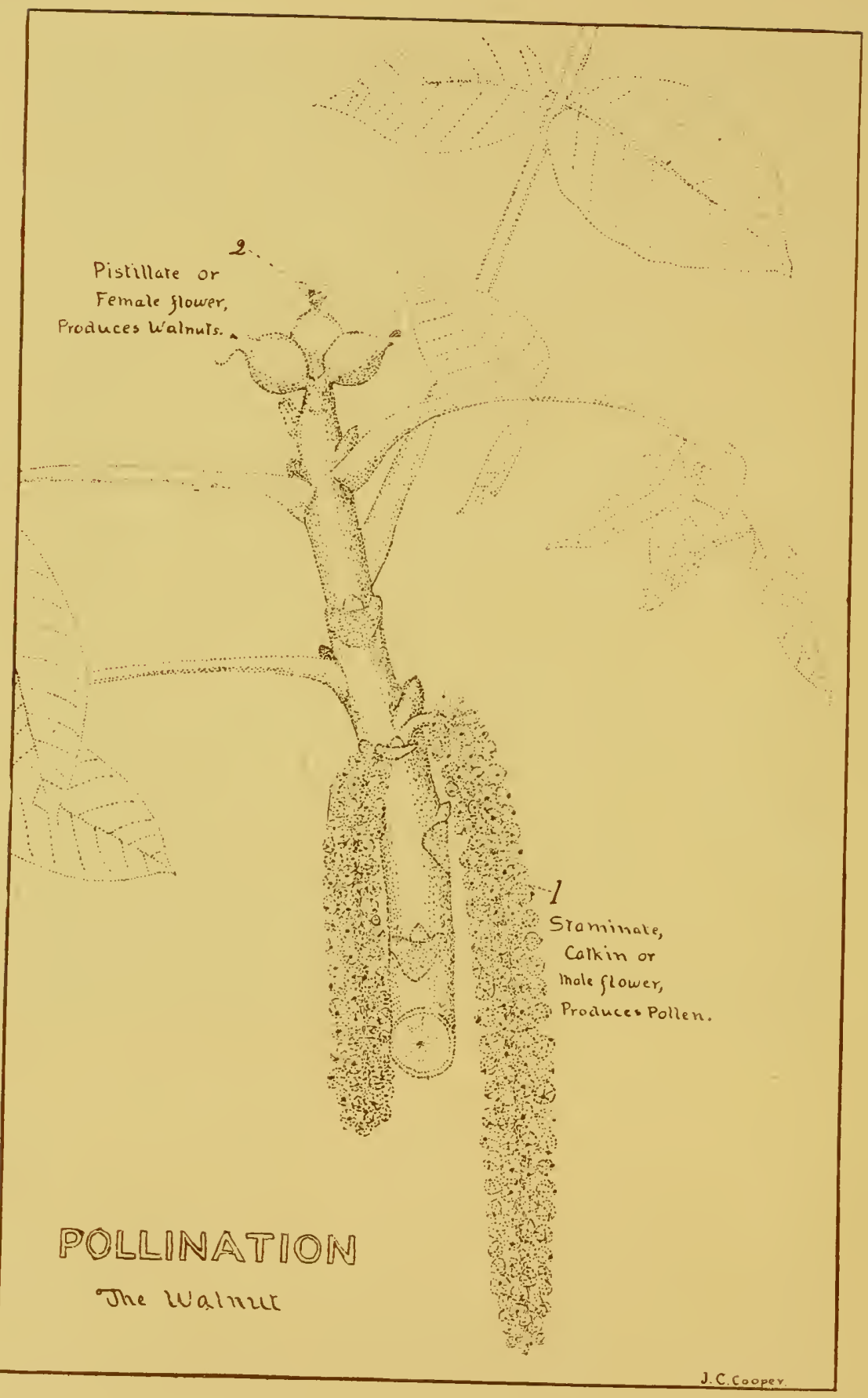




\section{WALNUT GROWING IN OREGON}

\section{POLLINATION}

Every fruit and mut grower shonld know the simple theory of pollination. When a tree apears thrifty but fails to produee, nine times in ten the trouble is with the pollination. The walnut is bi-sexinal and self-fertile; the staminate eatkins appear first. at the end of the year's growth (see Fig. 1), and the female blossoms, or pistillates, from one to three weeks later at the end of the new growth (see Fig. 2). Thus the staminate eatkins sometimes fall before the pistillates form, and naturally there is no pollination and no crop. This should not diseonrage the grower or cause him to uproot his trees. Often by waiting a few seasons-if the tree is of the correct variety-the trouble may right itself. Many growers have gotten a crop from single trees where there was trouble with the pollination by artifieially fertilizing, that is, shaking the pollen from fertile trees, even blaek walnut, over the barren pistillates. Birds. inseets, and the breezes carry pollen from one tree to another. Therefore, if muts for seed are desired, keep each grove of pure strain separate that there may be no deterioration owing to eross-fertilization. But the mixed orchard may bear best. Some varieties of walnut trees-notably the Los Angeles-are suitable only for shade in Oregon and shonld not be planted with any other thought in mind. The staminate blossoms of this variety appear six weeks ahead of the pistillates and, there being no pollination, naturally there are no muts.

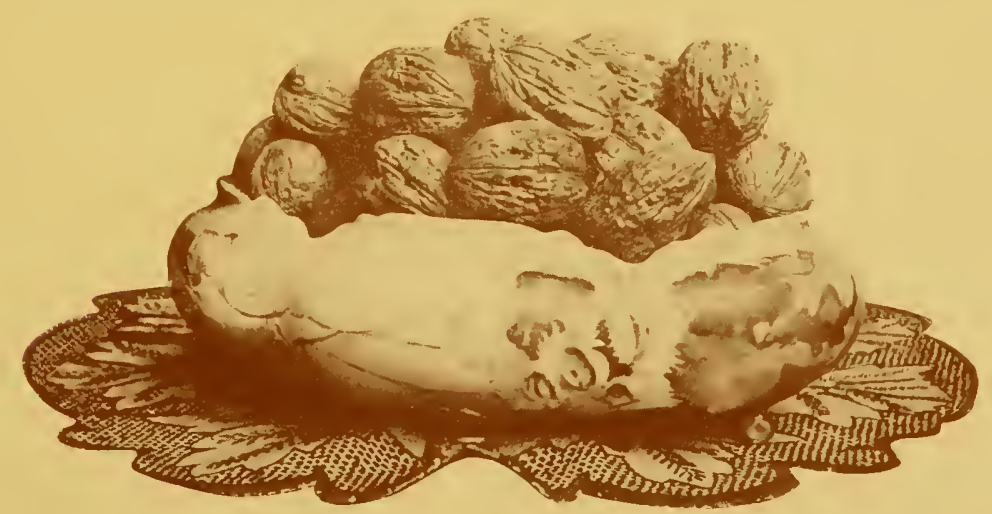

Best in the World, Oregon Walnuts 


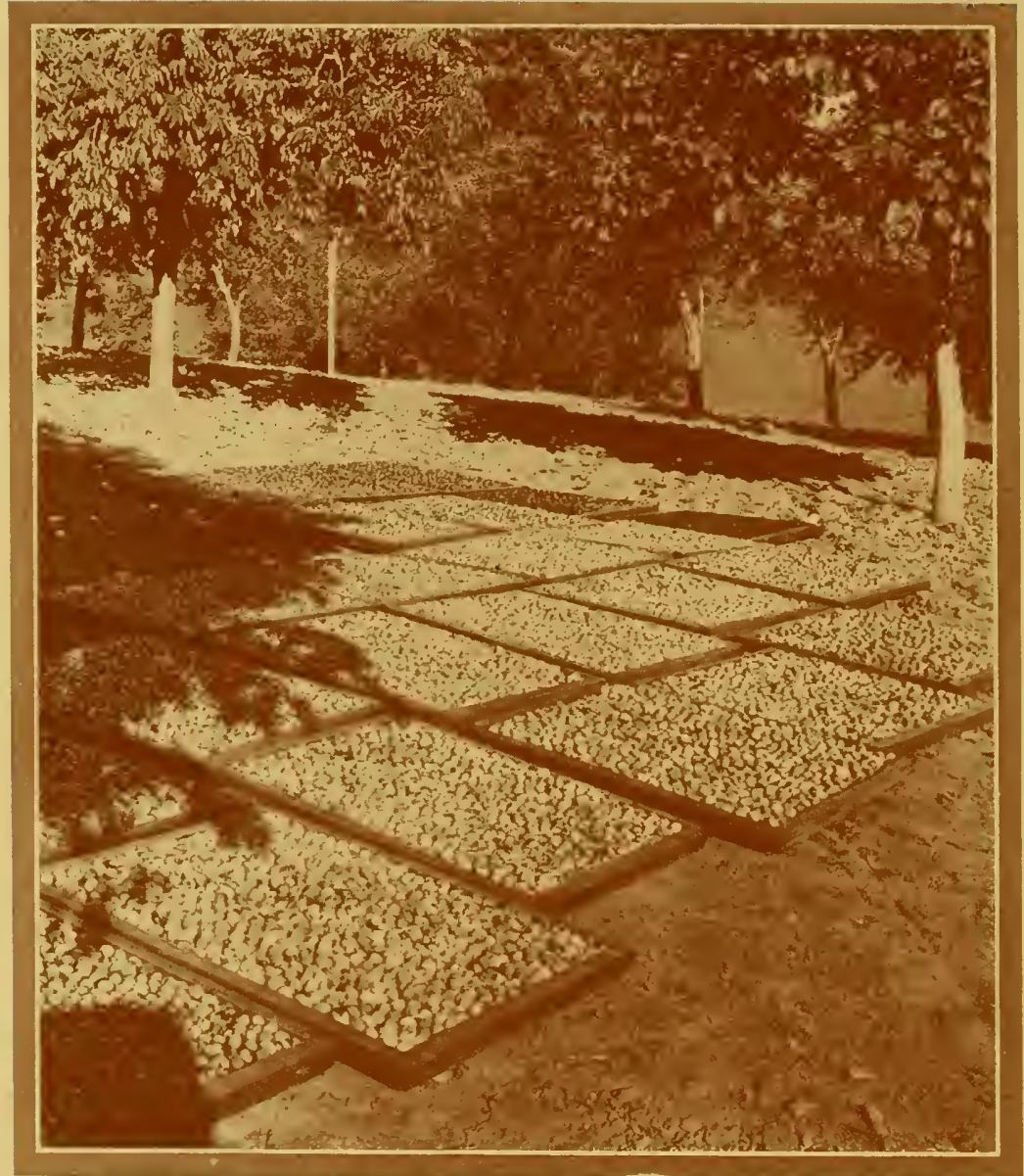

Drying the Nuts

\section{THE HARVEST}

The harvest comes in October, a convenient season where there are fruit crops to be taken care of. The process is extremely simple, being little more than an old-fashioned "nut gathering." When ripe, the muts fall to the ground, shedding their hulls on the way. They are picked up by boys. girls, men and women.

During the harvest three or four rounds must be made through the grove. perhaps a week elapsing between trips, each time slightly shaking the trees to make the ripe nuts fall. On the last round, a padded mallet with a long handle is used to dislodge the remaining nuts. The expense of harvesting is slight, five or six people being sufficient to care for a fifty-acre grove. 


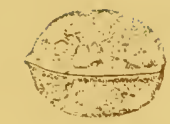

\section{WASHING AND DRYING}

When the nuts are gathered and bronght in they are put into a revolving barrel-churn holding about 12 to 16 gallons. Two buckets of water and ahout the same of walmots are put in together and the chmrn revolved for some minntes. Then the nuts are taken ont and spread on wire crates and placed in the sum; they should be raked over two or three times a las. Or. if the weather is wet, they may be placed in the dry-house in a good dranght at abont 70 degrees $F$. In an artificial drying if the heat becomes ton great the nnts will be rancicl. as the oil-cells will burst; so hetter err on the side of underheating than overheating. If left ont of doors, cover carefully to protect from dew. The erates for ontroor drying are placed on trestles in some California groves, in older that the air may cireulate throngh the nuts. This is much better than placing them on the gromed, where they draw dampness.

\section{SORTING AND GRADING}

After the walnuts are gathered, washed, dried and stored for a week or so to test the colpecotness of their drying, they are ready to be graded by passing orer a sized screen. The rhoicest ones will sell at top market prices. and the culls a little under. The Prince grove harrest is never graded, as he fincls ready sale at highest prices for the entire output just as it runs after sorting out the ferr imperfect nuts.

\section{PACKING AND SHIPPING}

They are next put into pound cartons. or 50-pound bags, common gumne sackis, rearly for the market.

Not heing perishable nonr are lost in shipping or by keeping. Walnuts from Oregon groves have been kept two years, tasting as sweet and fresh as those in their first season. Long lands are not objectionable, as the rough handling is not injurions to the well-sealed rarieties grown in Oregon. In this they have an adrantage over fruit. 


\section{WALNUT GROWING IN OREGON}

WALNUT YIELD PER ACRE

While it is generally fomd that seedling trees properly treated come into bealing the eighth rear, this crop is usually light, doubling each successive season for seren or eight years. From then on there is a strady increase in crop and hardiness for many rears. Often trees in Oregon hear in their sixth rear; while there are instances on recold of trees set ont in February bearing the following antumm. This is no criterion, however, merely an instance illustrating the umsual richmess of Oregon soil, and its perfect adaptability to walnut culture.

Thirty-five acres on the Prince plaee yielded at twelve rears, twelve tous of fine muts. which were sold at 18 and 20 cents a pound, two cents above the market price, making an average of $\$ 125$ per acre. Another grove of two acres yiclded in their ninth year two tons, or a ton to the acre, netting the owner $\$ 360$ an acre.

Mr. A. A. Quanubrg's eleven-year-old trees averaged twentyfive pounds each. Mr. Henry .J. Biddle's ten and twelve-year-old trees averaged thirty pounds each. One hundred fifty dollars an acre from twelve-year-old trees is a eonservative estimate, though some groves not cultivated may fall under that figure. while others in a high state of cultivation will almost double it.

\section{THE WALNUT MARKET}

The very fact that in 1907 Oregon-grown walnuts commanded several cents a pound higher price than those grown elsewhere indicates their market value. When ordinary nuts sold for 12 and 16 cents a pound Oregon nuts brought 18 and 20 cents.

New York dealers who cater to the costliest trade throughout the United States, and who have never handled for this purpose any but the finest types of imported muts, pronomnced the Oregon product satisfactory from every standpoint-finely flarored, nutty, meaty and delicions. They were glad to pay an extra price to secure all that were available.

In the home market the leading dealers of Portland and Northwest cities readily dispose of all of the Oregon walnuts obtainable at an advanced price. In fact, the Oregon walnut lias commanded a premium in every market into which it has been introduced. 


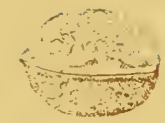

California walnuts are largely shipped east, the pereentage entering the northern markets being comparatively small. The anmul sum expended in Oregon for imported muts at the present time is $\$ 400,000$. When the Oregon growers are able to supply the home demand alone. shutting out importations, the population of Oregon wili have more than doublecl, and the amount expended in this state for walmuts will approach if it does not exceed the million-dollar mark. In addition to this the easter'n markets will be clamoring for Oregon walnuts, as they now absor?, Hood River apples. Willamette valley cherries and Rogue River valley pears. With eastern buyers always ready to pay an extra price for extra gracle procluets, superior grates of Oregon walmuts will undoubtedly be eontracted for, leaving only the culls for lome consumption.

It has been conservatively estimated that at the rate the population of the United States is increasing, and the rate walnut consmmption is increasing, by the time every available aero in Oregon is in full bearing the supply will still fall far short of the demand. Judging by past experienee in California this is no ehimerical conception. Since 1896 the walmut crop in that state has stradily increased, and in like proportion has the price advanced, from seven cents in 1896 to twenty eents in 1907.

\section{COMPARED WITH FRUIT}

In eomparing walnut culture with fruit, one must take into eonsideration the fact that distance from transportation facilities is not a detriment; that there is very little expense in putting ont or maintaining a waluut grove; that insects, blight and disease are unknown to walnut groves of Oregon, thus obviating the cost of spraying; that the expense of harvesting is exceedingly light; that no mut-fruit pexishes-that it does not need to be sold at once, hut will keep indefinitely, making a lost cop practically impossible.

It is estimated by experienced walmut growers that the anmual cost of (nltivation and pruning shombl not exceed $\$ 10$ an acre. while harvesting should not exreed 20 cents per hundred pounds. It is a simple matter to figme the profits.

The original investment in a walnut grove may be made a eomparatively small amomnt; thus it appeals partieularly to those of limited means. 


\section{WALNUT GROWING IN OREGON}

\section{THE POUND PACKAGE}

It is difficult or impossible to establish a uniform parkage grood for every rear. Traluuts are not like other fruits; size is not a sure inclication of weight. The pound package used by Mr. Thos. Prince is $33 \frac{1}{4} \times \frac{1}{6} \times 5 \frac{1}{4}$ inches. which in 1907 when filled weighed 17 ounces, in 1908 it weighed 16 onnces, and in the dry year of 190.9 it weighed but 14 omnoes.

\section{WALNUT CONFECTIONERY}

The "ut on page 5 shows the hest method of (.l'acking waluuts to extract the kernel in halves withont breaking. Grasp the nut between the thumb and forefinger at the seam. place on a hard surface of stome or irou and strike sharply with a light hammer

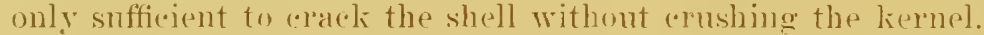

This method is used hy most manufacturers of great varieties of wahut confectionery, some of which are shom in the picture. Walnut chocolates, walnut taffy, walnut log, panoche, nougat and many other articles, as well as walmut sundries to put on dishes of ice cream are among the tasty confections for which the lemand is very great.

\section{WALNUTS IN COOKING}

A few of the delightful ways in which walunts may be used on the table:

\section{NUT BREAD}

1 pound hard wheat fiour.

1 pound whole wheat fiomr.

1 cup good reast.

1 cup groumd waluuts.

1 tablespoonful Orleans molasses.

2 tablespoonfuls melted lard or hutter.

Mix with warm water; let it raise quite light. then mould, raise and bake as other bread.

\section{GEMS}

Graham. wheatlet or cormmeal gems are greatly improved by adding a few walnut kemels gromnd fine.

\section{NUT CAKE}

3 eggs. yolks and whites beaten separately. 1/2 cup-scantbuttrr, 3/4 ('up milk. 1 (*up walnuts ground or chopped. 11.2 eups granulated sugar. 1,. teaspoonful each of lemon and vanilla, "2 teasponfuls baking powder. flowr to make a moderately stiff batter. 


\section{CHOCOLATE NUT CAKE}

3 eggs, $3 / 4$ eup each of brown and white sugar. $3 / 4$ cup of coffee and milk mixed, 1 cup spound walnuts, 4 tablespoonfuls melted butter, 2 teaspoonfuls gromel chorolate or cocoa. most of 1 nutmeg grated, 2 teasponfuls baling powler. Hom to make moderately stiff baltter.

More satisfartory results are obtained hy baking either of these cakes in two deep layercake tims and putting the two parts together with any good filling.

\section{NUT COOKIES}

3 cups sugar-Extra ( preferrecl-3/4 poumd of hutter, 2 or 3 eggs, 1 cup of water, 1 teaspoonful of haking powder. 1/. a nutmegg, a little ginger and cinmamom. 1 ('llp walnuts gromed fine, 4 cups of flour. Roll thin and bake in a ruick oven.

\section{APPLE NUT SALAD}

4 cups of good tart apples cut in small cubes or ahopper not too fine, 1 cup of coarsely ground, or choppocl nuts. Stir lightly into these 1 cup of sugar and $1 / 2$ of a nutmeg grated fine.

\section{DRESSING FOR SAME}

2-3 cup of cold water, 2 tablespoons strong vinegar, 1/2 eup of sugar. Add one egg. well beaten. Put this on the stove and stir constantly until well cooked. If this is clone carefully it will not eunle. Take from the stove and add a lump of butter the size of a walnut, grate in a little nutmeg and stir gently until the butter is well melted and mixed. Some whipped cream may be added to this when cool if desired or convenient.

\section{BY-PRODUCTS}

In addition to walunts as muts, they pay handsomely as pickles. For this purpose they must be picked green. This could be made a most profitable side industry in comnection with large groves.

One grower harl an inquiry for two carloads of green walnuts to be used for this purpose. Large quantities are imported anmually and they sell at very high prices.

They are also used for dyeing purposes. giving a heautiful brown shade difficult to obtain exeept with walnut hulls.

Oil which is often substituted for olive oil is manufartured from walnuts, thus suggesting another commercial arenue. One hundred pounds of walnuts produce righteen pounds of oil. 


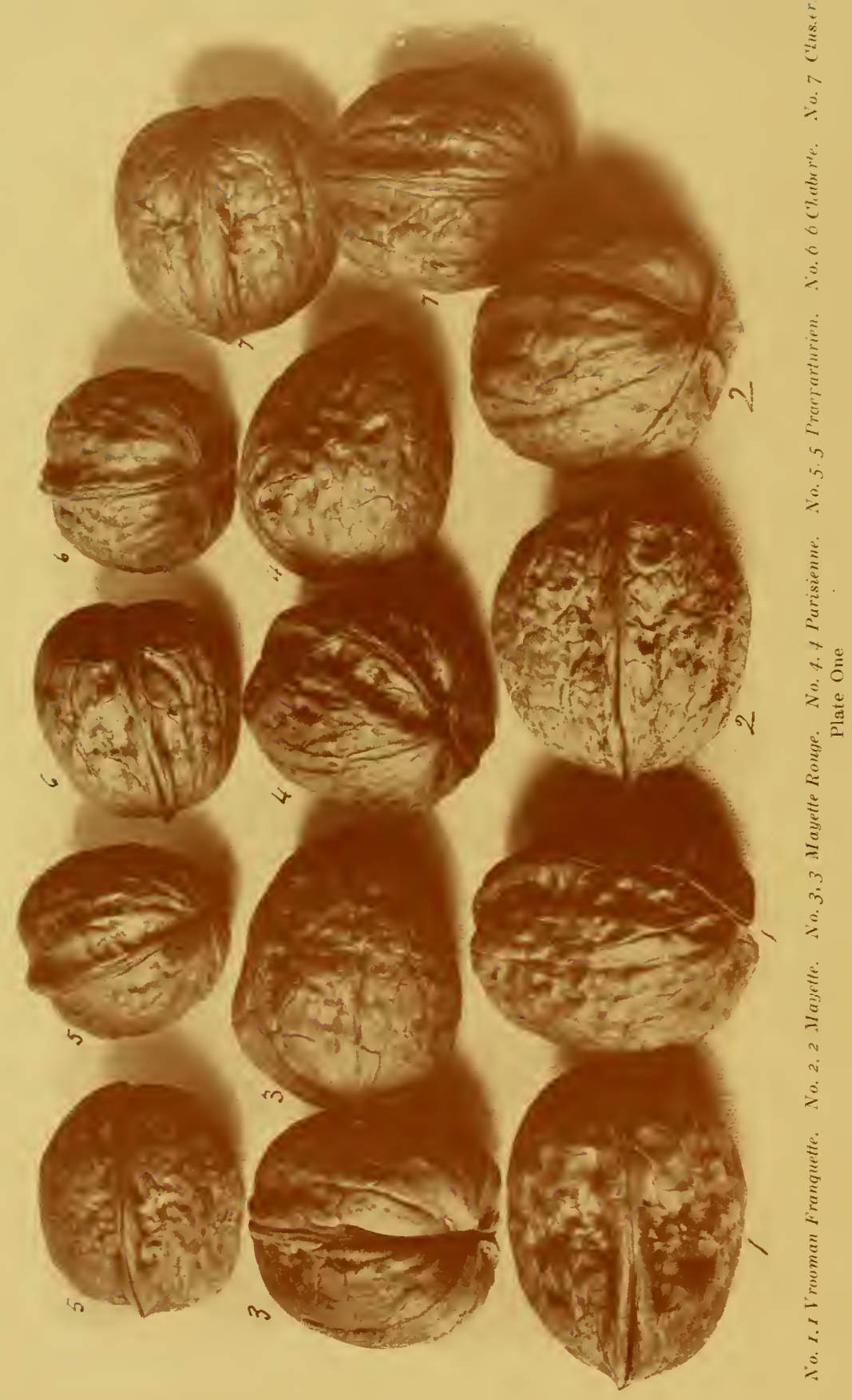




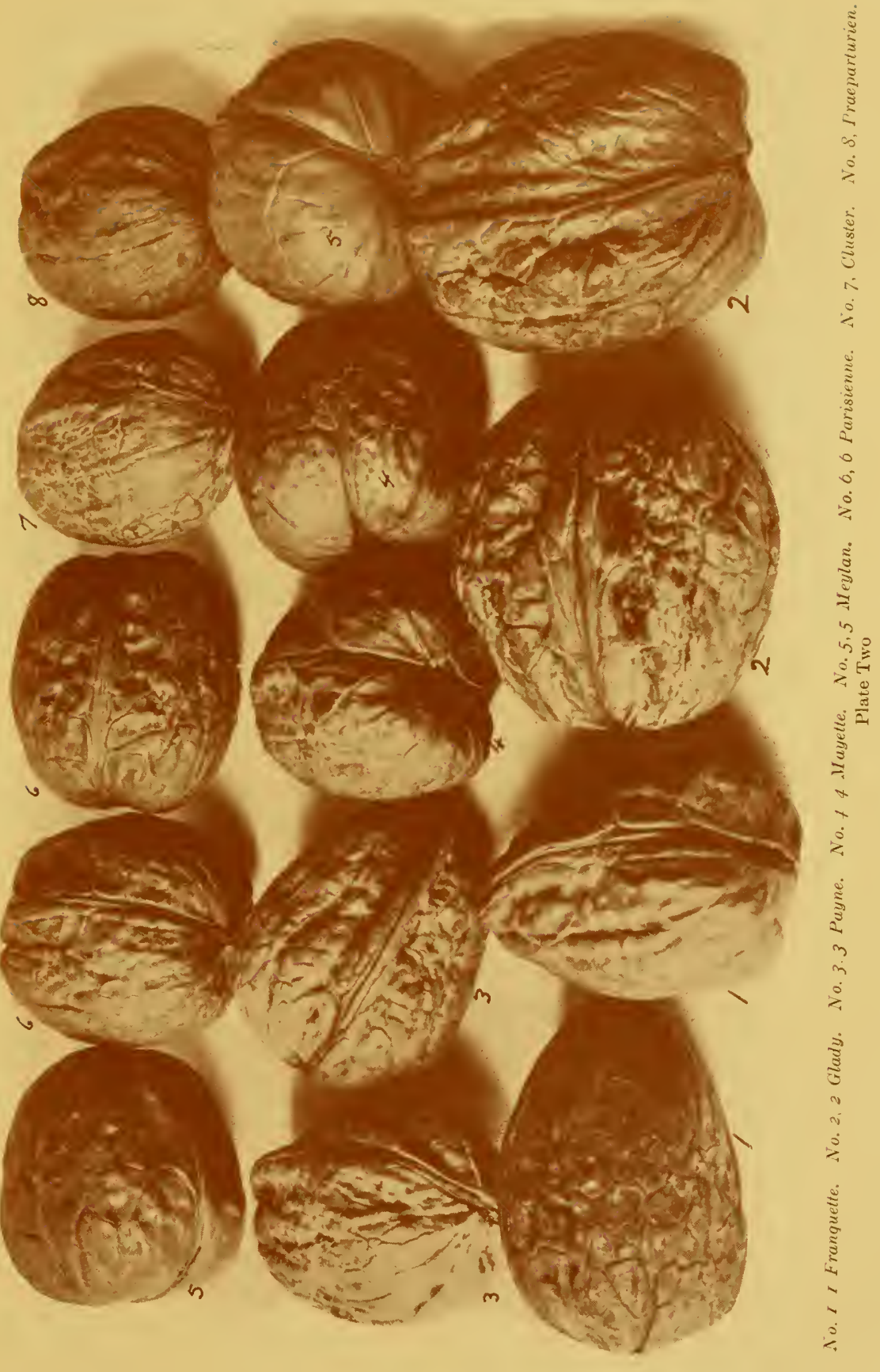




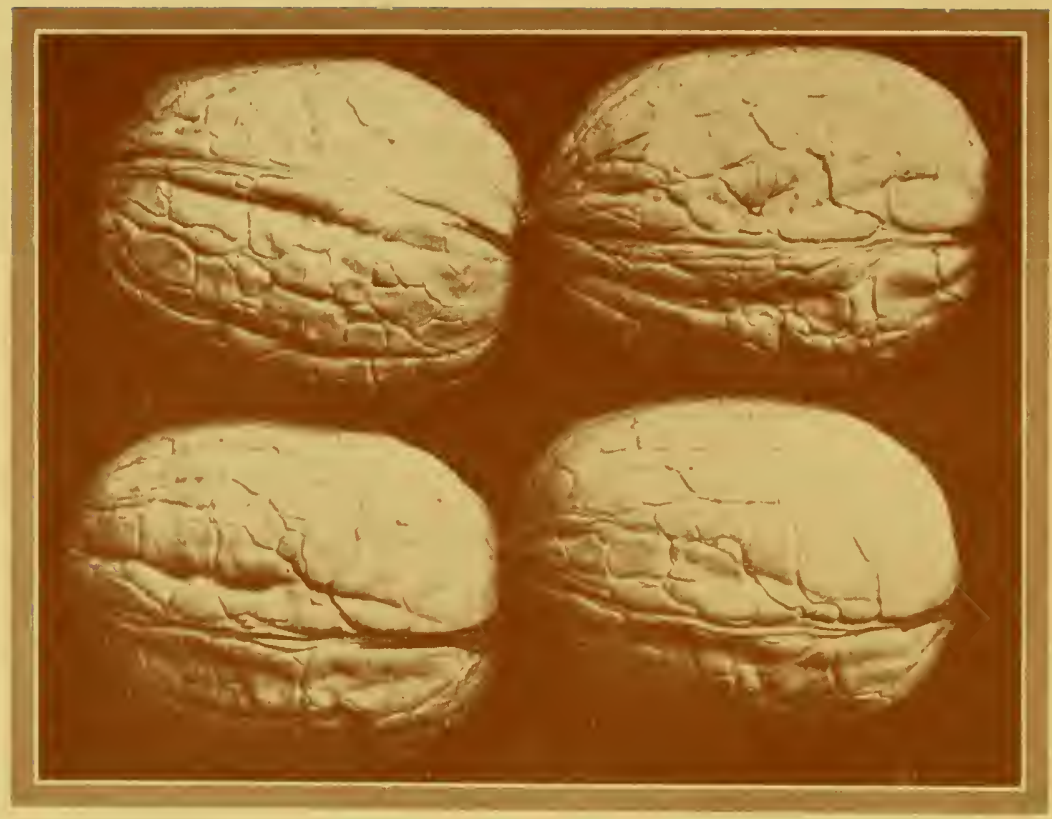

Plate Three

The "Prince of Yambill"

\section{VARIETIES}

The beantiful muts shown on Plate 3 are seedlings frou the orchard of Mr. Thomas Prince, of Yamhill rounty. They are probably the handsomest walnut as to size, form and color as well as taste that may be fonnd anywhere. The tree has not had an orchard try-ont ret. It if proves to be a good bearer with the other "qualities suitable for this dinate and soil "ondition, it will enter the field high np in the standard of excellence.

There is some discrepancy in what constitutes standard varieties of walunts. We have endeavored to get nuts both from Oregon and california to fix a miform molerstanding as to the different varieties. The types subnitted by Mr. A. MreGill of the Oregon Nursery ('o.. l'late 1, are No. 1. 1 Vroman Franquette, No. 2, 2 Mayette. No. 3, 3 Mayette Rouge, No. t, 4 Parisienne, No. 5, 5 Praeparturien, No. 6, 6 Chaberte, No. 7, Chuster.

Plate No. 2, by Mr. Ferd Gromer, No. 1, 1 Franquette, No. 2, 2 Glady. No. 3, 3 Payne, No. t. + Ilayette, No. 5, 5 Meylan, No. 6. 6 Parisienne, No. 7 ('luster. No. S Preparturien, are ahont as near miformly rolreet as we have. 


\section{WALNUT GROWING IN OREGON}

The Chaberte muts. which eonfoctioners nse, are a special industry, the kernels being slipped ont of the shells withont breaking, and sold in this form. All the smaller muts, the imperfect ones--the rulls--find ready sale both sbelled and unshelled for the manufarture of walnut randy, walnut rake, ot".

\section{WEIGHTS. KERNEL AND TASTE}

The first Walmut Show was held at Mr.Minmville. November 1, 1907, and was judged by H. M. Williamson, Secretary of the State Board of IIorticulture. Most of the following memoranda on weights are taken from his report:

James Morrison, Franquette...........32 to the pound

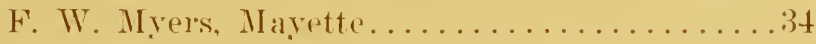

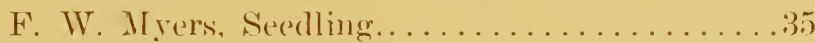

James Morrison, Scedling Franquette ........t2 James Morrison, Grafted Mayette ..........38

D. H. Turner, Seedlings. . . . . . . . . . . 42

James Morrison, Blancle Mayette ..........34

James Morrison. Grenoble Mayettr . . . . . . . 32

D. H. Turner, I'arry................

Mavette Shaped Proeparturiens..........6t

R. P. Ungerman, Seerllings. . . . . . . . . .50

Bland Herring, Proeparturiens............38

Bland Iterring, Bijon ... . . . . . . . . . 22

Pleasant Cozine, Seedlings..............42

Casey tree, Seedling ...............55

E. Estes, fourth generation from Casey tree. . .52

Thos. Prince Seedling ... . . . . . . . . . . 40

Derr Tree, Parry...................60

, 6 , 6

, $\cdots$

The investigations in regard to relative weights of kernel and shell of the different varieties is made up from an article read by Mr. Ferd Groner before the State Horticultural Society, Decenther, 1909 .

The Vrooman Franquette shell and kernel weighed erpal.

The Payne Seedling gave slightly more kernel than shell.

The Mayette slightly more shell than kernel.

The Meylan, shell aud kernel equal.

The Gladys, shell and kernel equal.

Franquette. near Salem, shell weighed two ant one-half times that of kernel. 


\section{WALNUT GROWING IN OREGON}

Other experiments show that the l'roeparturien shell and kernel are about equal.

While the woight of the kernel is of great importanee to the consumer, the taste and digestibility is still more so. In this is the food value of the walmut. The food value will in time be the commereial value. There is very little variation in the taste of any one variety of wild nuts or fruits, but the cultivated walnut, as well as the cultirated peach and apple. has a great variety of tastes, and it does not require an expert to distinguish the good from the poor qualities.

Walnuts should he graded as to variety, the varieties should then be graded as to size. but the paramount duty of the grower is to produce a ereamy. delieions walnut of excellent flavor. The soil and climate has proven their excellenee, and it is now for the intelligent grower to do his part.

\section{WHO SHOULD INVEST}

Professional men and women, business men and women. those living in eities and towns and eonfined to offices, stores and factories. will find an investment in forty or fifty acres of walnut land at the present time wholly within their possibilities. Special terms ean be arranged and their groves planted and cared for at small eost. While they are working their groves will be growing toward maturity, and in less than a decade they may be frec from the demands of daily routine: the grove will fumish an income, increasing cach season until the twenticth year, and will prove the most pleasant lind of old age annuity, and the lichest inheritance a man could leave his children.

The practical farmer, or the inexperienced man who desires to escape the tymann of city work by way of the soil will find that a wahnut grove offors an immerliate home, a living from small fruits and vegetables while his trees are maturing, and at the end of eight or ten yoars, the begiming of an income that will every year thereafter increase. while the lahor exacted will gradually lessen mutil it amomuts to practic*ally nothing. Like rearing children, a walmut grower's trombles are over with the trees' infant dats.

The capitalist can find no better place for his money than safely invested in Oregon walunt lands; the rise is certain and near. 


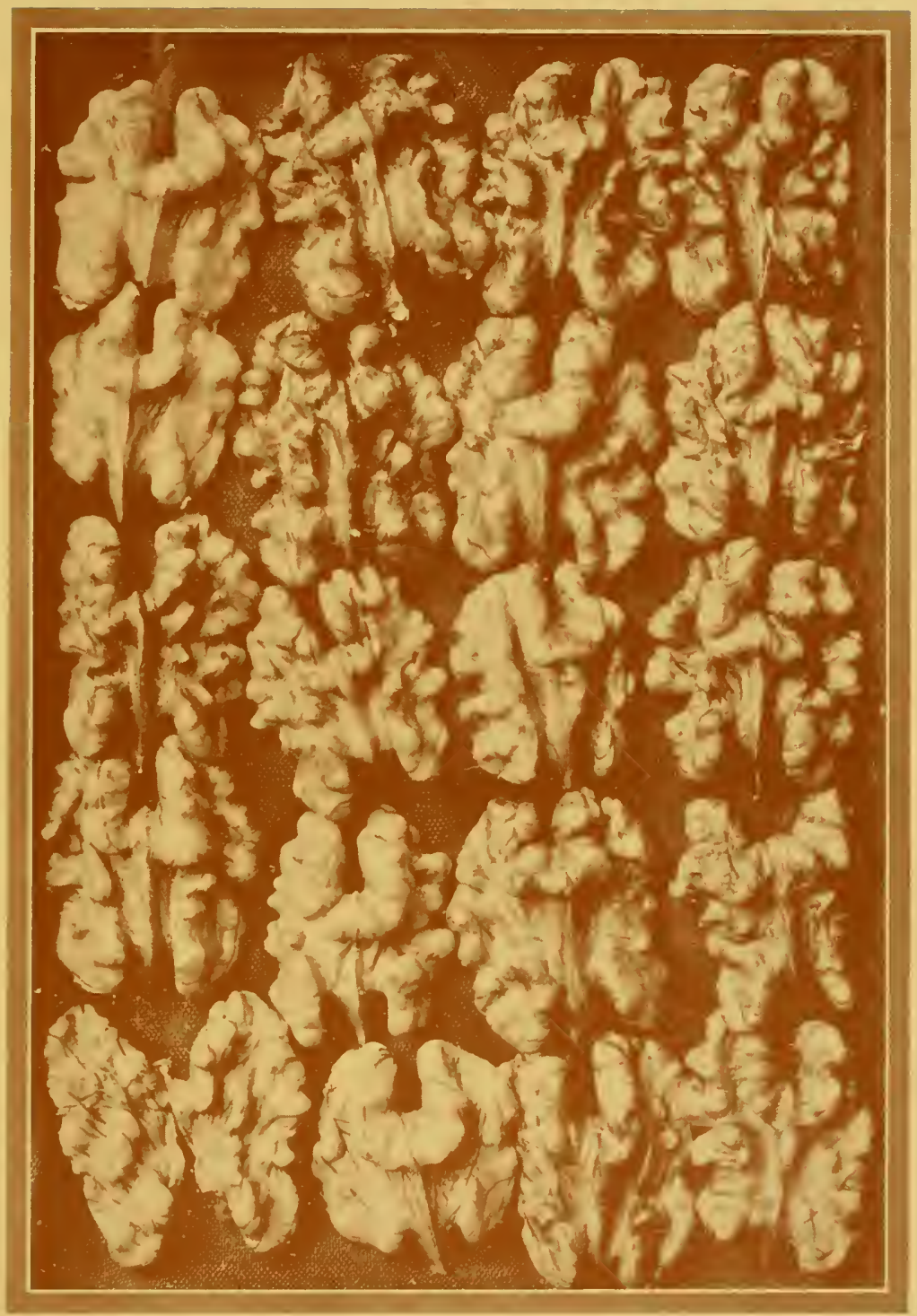

The "Meat" of the Walnut

Some years ago "Outlook." a most conservative publication, spoke of the English walnut as "a tree of vast commercial importance in the far west."

Luther Burbank states: "The comsumption of walnuts is increasing among all cirilized nations faster than any other food.' 


\section{WALNUT GROWING IN OREGON}

\section{CONCLUSION}

13. M. Lelong. Secrertary of the California State Boarr of IIorticulture. wrote in 1896 :

"California guowers have had a long and varied experiences with many failures. and when they finally began to place their walnuts on the market they were obliged to accept the humiliating price of from 3 to 6 cents a pound less than that paid for imported walmuts."

In Oregon the reverse is true. Onr walnuts above that paid for walnuts raised anywere else. The size, racking-out quantity, delicate Havor and delicious creamy taste. are the cmalities that give the Oregon walunt its smpassing excellence. If we have this pre-eminence at the begiming of the industry, what may we expect when intelligent enltivation has produced the best grade of wahnts of which our soil and climate are capable?

To Oregon, then. with its rast areas adapted to this industry. must the world look for its great anmual walnut harvest in the years to come. The far-seeing man will secure an interest in Oregon walmut lands now, before speculation and a general awakening to their real ralue have boosted the price to that of walnut lands elsewhere.

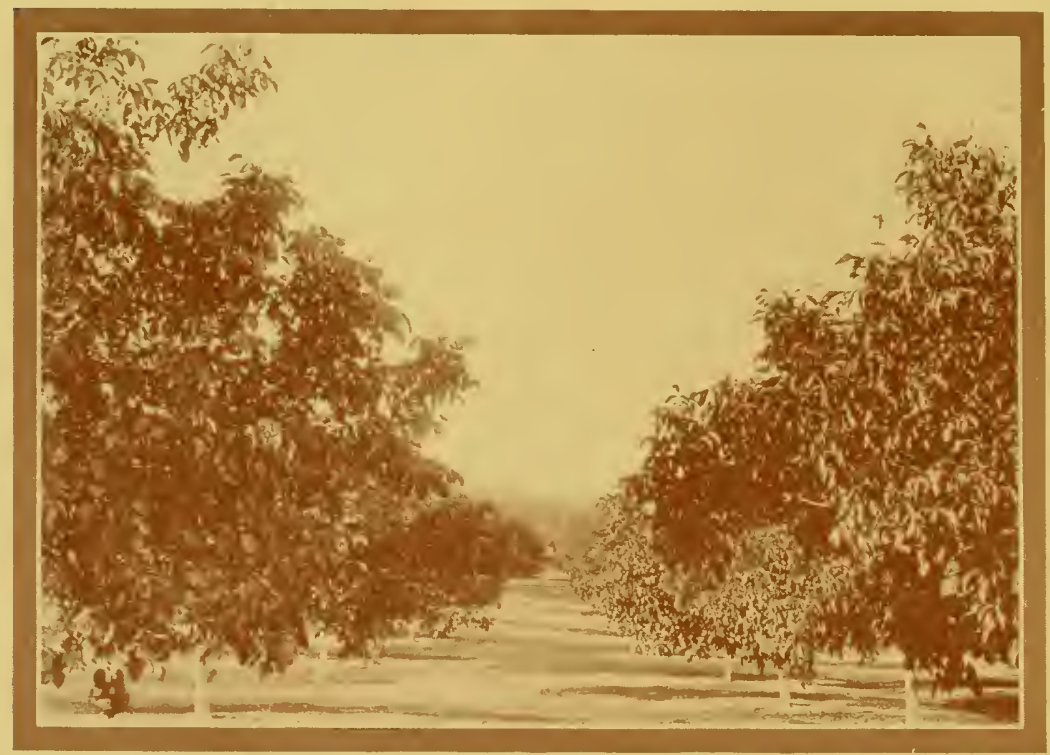

Tiew in Prince Tralnut Grove Dundee, Oregon 


\section{WALNUT GROWING IN OREGON}

\section{OREGON WALNUT AREA BY COUNTIES}

Note: The price of land varies aceolding to location; the cheaper land is not all cleared.

\begin{tabular}{|c|c|c|c|c|}
\hline & $\begin{array}{l}\text { Groves now } \\
\text { planted. }\end{array}$ & Bearing trees. & Arailable land. & $\begin{array}{l}\text { Price } \\
\text { per acre. }\end{array}$ \\
\hline Vast & $\begin{array}{l}\text { Many young } \\
\text { ones. }\end{array}$ & $\begin{array}{l}\text { A number bear } \\
\text { full crons. }\end{array}$ & Thousands of & \\
\hline Multnomah & Several young & Many scattered. & Several & \\
\hline Yamhill & $\begin{array}{l}\text { groves. } \\
3.000 \text { acres. }\end{array}$ & 5.000 trees. & $\begin{array}{l}\text { thousand. } \\
40,000 \text { acres; } \\
\text { tvery quarter } \\
\text { rection has } \\
\text { suitable land. }\end{array}$ & $\$ 50$ to $\$ \geq 50$. \\
\hline Clackamas & 100 acres. & $\begin{array}{l}\text { Many scattered; } \\
\text { one grore. }\end{array}$ & ; Several & 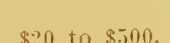 \\
\hline Polk & $\begin{array}{l}\text { Several hundred } \\
\text { acres }\end{array}$ & 100 trees. & Many thousand. & 25 to $\$ 100$ \\
\hline Marion & A few & $\begin{array}{l}\text { A number in } \\
\text { bealing. }\end{array}$ & $\begin{array}{l}\text { Hundreds } \\
\text { of acres. }\end{array}$ & $\$ 20$ to $\$ 500$ \\
\hline $\begin{array}{l}\text { Benton } \\
\text { Limn }\end{array}$ & $\begin{array}{l}\text { No record. } \\
\text { Sereral young }\end{array}$ & $\begin{array}{l}\text { No record. } \\
\text { Sereral }\end{array}$ & $\begin{array}{l}\text { Many acres } \\
\text { Many hundred }\end{array}$ & $\$ 20$ to $\$ 100$. \\
\hline Lane & $\begin{array}{l}\text { groves. } \\
300 \text { acies. }\end{array}$ & $\begin{array}{l}\text { scattered. } \\
\text { A few scattered; } \\
\text { bear hearily. }\end{array}$ & & $\begin{array}{l}\$ 20 \text { to } \$ 500 . \\
\$ 60 \text { to } \$ 125 .\end{array}$ \\
\hline Douglas & None. & $\begin{array}{l}\text { Mans; loaded } \\
\text { with nuts. }\end{array}$ & $\begin{array}{l}\text { Thousands } \\
\text { of acres. }\end{array}$ & $\$ 25$ to $\$ 100$. \\
\hline Josephine & No record. & $\begin{array}{l}\text { A number; } \\
\text { scattered. }\end{array}$ & $\begin{array}{l}\text { Hundreds } \\
\text { of acres. }\end{array}$ & No record? \\
\hline Jackson & 30 or 40 acres. & $\begin{array}{l}\text { Hundreds scat- } \\
\text { tered through } \\
\text { valley loaded } \\
\text { with nuts. }\end{array}$ & $\begin{array}{l}\text { Several } \\
\text { thousand. }\end{array}$ & $\$ 25$ to $\$ 225$. \\
\hline $\begin{array}{l}\text { Baker } \\
\text { (Eastern }\end{array}$ & A few groves. & $\begin{array}{l}\text { Many producing } \\
\text { trees. }\end{array}$ & $\begin{array}{l}\text { Thousands } \\
\text { acres. }\end{array}$ & $\$ 25$ to $\$ 150$ \\
\hline
\end{tabular}

\section{GOLD MEDAL WALNUT EXHIBIT}

(Fee cut on following page)

Last year the Walnut club of McNinnville made an exhibit of home grown waluuts at the A.-Y.-l'. Exposition and was awarded a gold medal. They have a very attractive and artistic ray of putting up an exhibit, rlassifying and arranging the different varicties in glass cases in such a mamner as to attract universal attention and (*all forth the heartiest exclamations of admiration. The acoompanying cut shows one of their exhibits in position. It is nine feet high and nearly five feet wide and is fared alike on both sicle.

This club was organized for the purpose of studying the walnut industry in all its details. They employ scientists and experts to tell how and to demonstrate the various methods of walnut culture. There are scores of 5 and 10-acre tracts planted to walnuts in the vicinity, as well as experimental trees on the lots in town and along the streets. They call MeMinnville "The Walnut City.', 


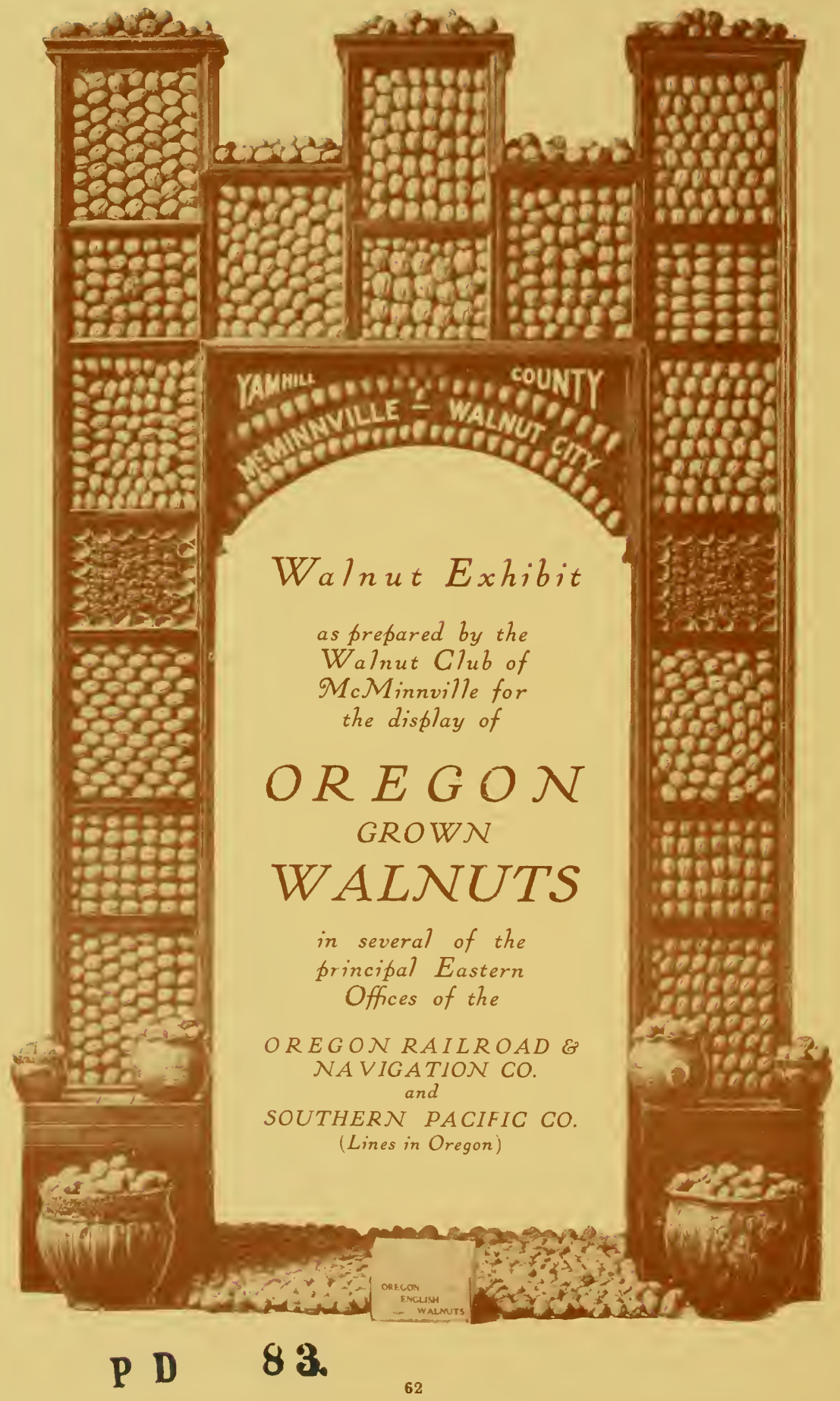




\section{RAILROAD REPRESENTATIVES}

Who will take pleasure in giving all desired information as to rates, routes, train schedules, hotel accommodations, etc., and make advance arrangements for trips.

\section{EAST.}

New York.........J. B. DeFriest, Gen. Eastern Agt., U. P. R. R., 287 Broadway New York.......... L. H. Nutting, Gen. Pass. Agt., S. P. S. S. Co., 366 Broadway Boston, Mass..........Willard Massey, N. E. Frt. \& Pass. Agt., 1i6 Wash. St. Philadelphia, Pa........... C. Milbourne, G. A., U. P. R. R., 830 Chestnut St. R. J. Smith, Agent, S. P. Co., 632 Chestnut St. Pittsburg, Pa................... G. Herring, General Agent, 707 Park Bldg. Cincinnati, Ohio...........W. H. Connor, General Agent, 53 East Fourth St. Detroit, Mich................ C. Ferguson. General Agent. 11 Fort St.. West

MIDDLE WEST.

Chicago, III............W. G. Neimyer, General Agent, 120 Jackson Boulevard St. Louis, Mo.................. G. Lowe, General Agent, 903 Olive St. Kansas City, Mo.

H. G. Kaill, Asst. Gen. Frt. \& Pass. Agt., U. P. R. R., 901 Walnut St. St. Joseph, Mo......... E. Stohr, Gen. Frt. \& Pass. Agt., St. J. \& G. I. R. R. Leavenworth, Kan......J. J. Hartnett, Gen. Agt., Rooms 9-11 Nat. Bank Bldg. Council Bluffs, lowa...........J. C. Mitchell, City Ticket Agent, 5⒉ Broadway Des Moines, lowa.............J. W. Turtle. Trav. Pass. Agt., 313 W. Fifth St. Minneapolis, Minn........... F. Carter, Dist. Pass. Agent, 21 South Third St. Lincoln, Neb........................ Slosson, General Agent, 1044 O St. Omaha, Neb.............. L. Lnmax, General Passenger Agent, U. P. R. R. Pueblo, Colo.................. M. Tudor, Commercial Agent, 312 N. Main St. Denver, Colo.............Francis B. Choate, General Agent, 941 Seventeenth St. W'm. K. McAllister. Gen. Agt., S. P. Co.. Suite 313 Railway Exc. Bldg.

\section{CANADA}

Toronto. J. O. Goodsell, Traveling Pass. Agt., Room 14 Janes Bldg. SOUTH AND SOUTHWEST.

Atlanta, Ga.................. J. Dutcher, General Agent, 121 Peachtree St.

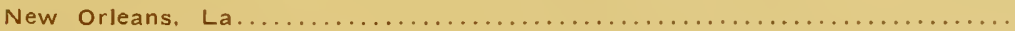

J. H. R. Parsons, Gen. Pass. Agt., M. L. \& T. R. R., 22T St. Charles St. Houston, Tex.......... J. Anderson. Gen. Pass. Agent, G. H. \& S. A. R. R.

\section{EUROPE.}

London, England................Rudolph Falck, General European Agent No. 49 Leadenhall St. E. C. No. 2-2 Cockspur St., N. II:

Liverpool, England............................. 25 Water St. Antwerp, Belgium.......................... Rue Chapelle de Grace Hamburg, Germany................ Amerika Haus, 23-27, Ferdinand Strasse

\section{PACIFIC COAST.}

San Francisco, Cal......Chas. S. Fee, Pass. Traffic Migr. S. P. Co., Flood Pldg. Lewiston, Ida.............. W. Mount, District Freight \& Passenger Agent Los Angeles, Cal............. O. Wilson, Gen. Agt., U. P. R. R.. 557 Spring St. T. A. Graham, Asst. Gen. Pass. Agt., S. P Co, 600 s. Spring St. Olympia, Wash...................... C. Percival, Agent, Percival's Dock Salt Lake City. Utah.......... D. E. Burley, Gen. Pass. Agt., O. S. L. R. R. Seattle, Wash.........W. D. Skinner. Gen. Frt. \& Pass. Agent, O. \& W. R. R. E. E. Ellis, General Agent, 608 First Are.

Tacoma, Wash... Robt. Lee, Gen'l Agt., Berlin Bldg., Eleventh and Pacific Ave. Spokane, Wash............. C. Munson, City Ticket Agent, 601 Sprague Ave. Walla Wala, Wash............. Burns, District Freight and Passenger Agent

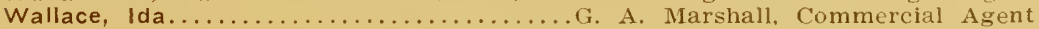
Astoria, Ore.............. W. Roberts, Commercial Agent, O. R. \& N. Dock Portland, Ore........... W. Stinger, City Ticket Agent, 3d and Washington Sts.

R. B. MILLER, Traffic Manager WM. MCMURRAY, Gen. Pass. Agt. JOHN M. SCOTT, Assistant General Passenger Agent

\section{Portiand, Oregon.".}




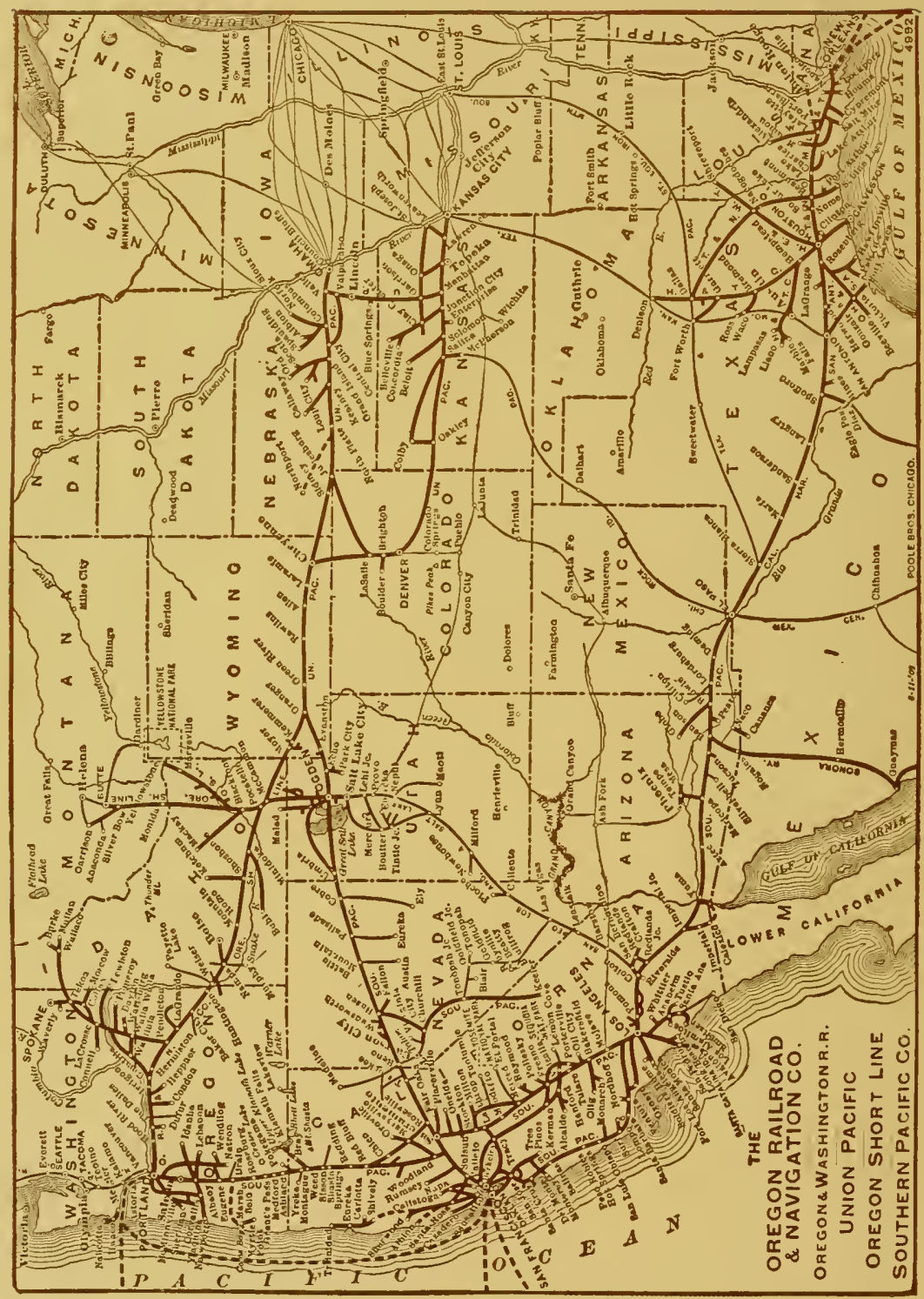

FUв, $29 \quad 4.20-10$ 10M 
One copy del. to Cat. Div. 2u2 25 me 


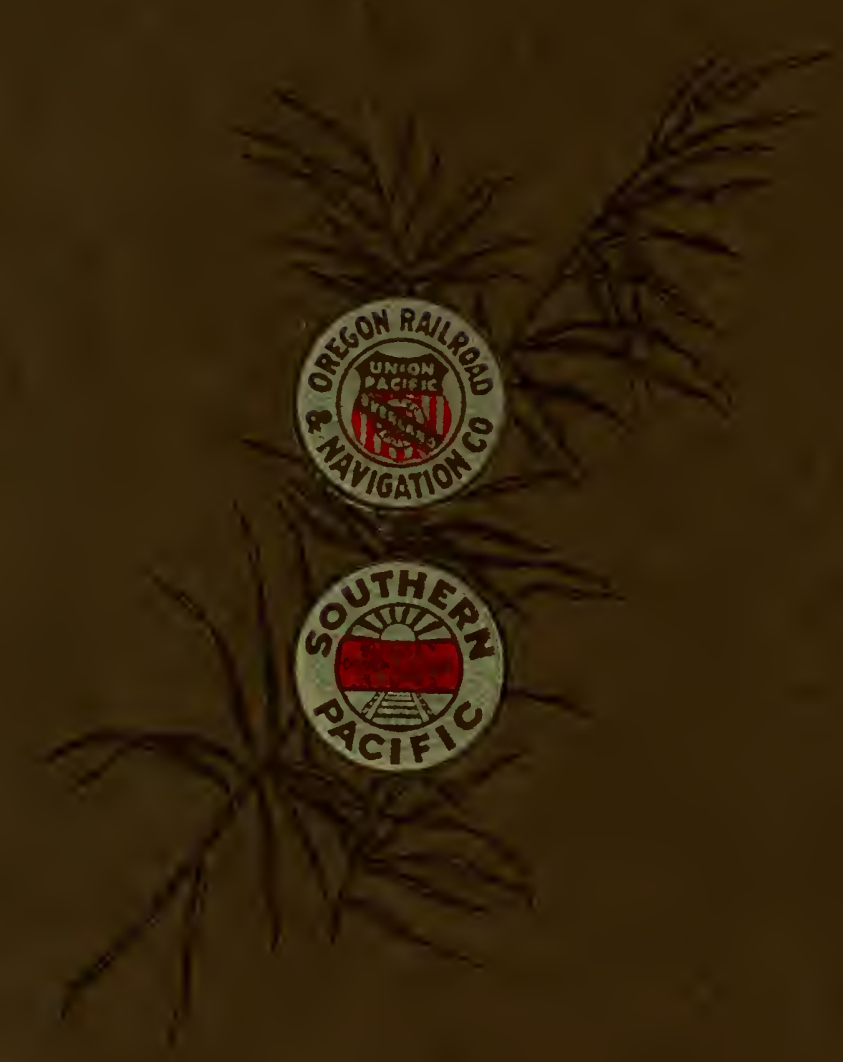







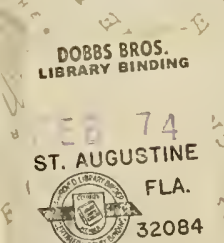




\section{LIBRARY OF CONGRESS \\ |||| || || |||||||||||||||||||||||||||||||||||

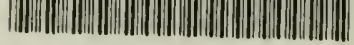 \\ 00009188824}

